\author{
OFFICE OF NAVAL RESEARCH \\ CONTRACT N6 Or $1-195, T .0 .1$ \\ NR-083-003
}
SONIC FISHES OF THE PACIFIC
by

Marie Poland Fish

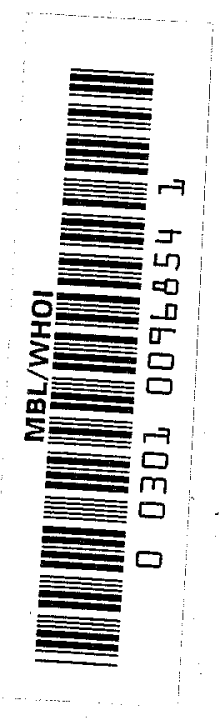

WOODS HOLE OCEANOGRAPHIC INSTITUTION

HOODS HOLE, MASSACHUSETTS

Technical Report No. $\underline{2}$

Edited by Chas.JoFlsh, Supervisor August 24,1948 
The present report is concerned with one of the oceanic biology subjects designated by the Navy for investigation. In compliance with the assignment the objective has been (I) to assemble, analyze and where possible correlate with environmental factors, available information from the central and western North Pacific, and (2) upon completion of this work to prepare recommendations for further field research designed to fulfill Navy requirements. A proposed program will be presented in a separate report. 


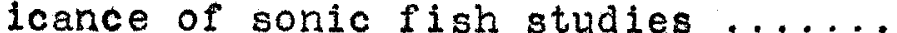

Procedure ....................... 7

Objectives ....................... 12

DISCUSSION OF SONIC SFECIES ............ 13

Family Acanthuridae: Surgeonfishes ....... 13

Family Angullidae: True eels ........... 14

Family Balistidae: Triggerfishes ........ 15

Family Batrachoididae: Toadfishes ........ 19

Family Brotulidae: Brotulid eels ......... 23

Family Caproidae: Boar-fishes .......... 24

Family Carangldae: Pampanos ............ 25

Family Cephalacanthidae: Flying eurnards . 31

Family Clupeidae: Herrings .......... 32

Family Cottidae: Sculpins ........... 34

Family Diodontidae: Burrfish .......... 37

Family Dorosomidae: Gizzard shad ....... 38

Family Ephlppidae: Spadefish .......... 38

Family Gadidae: Codfishes ............ 40

Family Gasterosteidae: Sticklebacks ...... 41

Family Hemiramphidae: Halfbeaks ......... 42

Family Holocentridae: Squirrelfishes ..... 44

Family Leiognathidae: Pouters ......... 45

Family Wacrorhamphosidae: Snipefishes .... 47

Family Molidae: Ocean sunfish ......... 47

Family Monacanthidae: Filefishes ........ 49

Family Monocentridae: Pine-cone fishes... 51

Family ophichthyidae: Snake eels ....... 51

Family ophidildae: Cusk eels ........... 53

Family oplegnathidae: Loros ........... 54

Family Ostracildae: Trunkfish .......... 55

Family Fempheridae: Catalufas .......... 56

Family Feristedildae: Deepwater Eurnards. 57

Family Petromyzonidae: Lampreys ........ 58

Family Pomacentridae: Demoiselles ....... 59

Family Pomadasyidae: Grunts ........... 63

Family Sciaenidae: Croakers .......... 66

Family Scombridae: Hackerels .......... 85

Family Scorpaenidae: Rockfishes ......... 91

Families of Siluroldea: Catfishes ........ 92

Family Sparidae: Porgies ............. 97

Family Syngnathidae: Pipefishes .................. 98

Family Teraponidae: Theraponids ........ 99

Family Tetraodontidae: Fuffers .......... 100

Family Triacanthidae: 3-spined filefish .. 101

Family $\operatorname{Tr} i g l i d a e:$ Gurnards ........... 102

Family Zeialae: John Dories ........... 107 


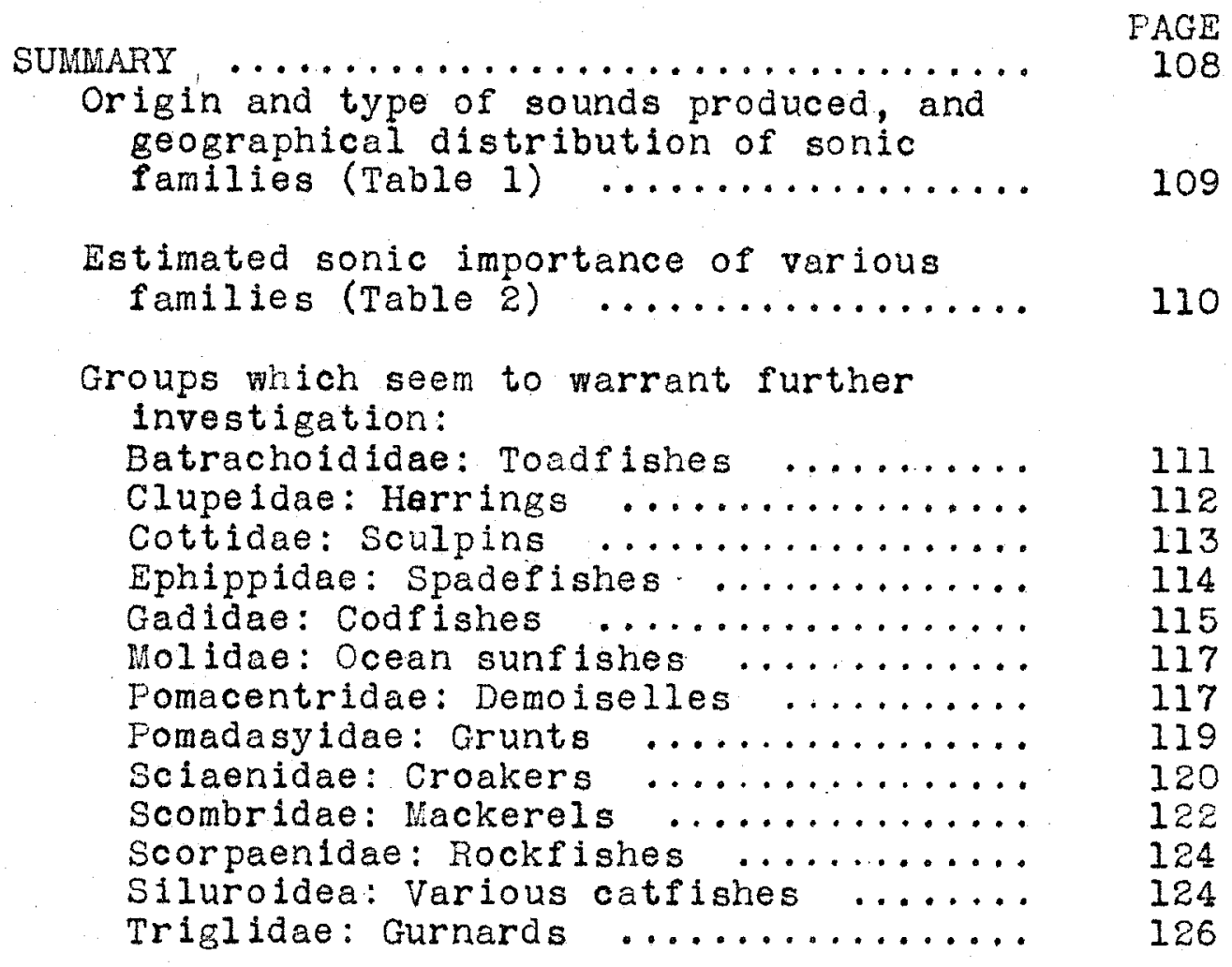

Areas and species suggested for sound measurement studies:

Northern Pacific coast of North America



Southern Pacific coast of North and

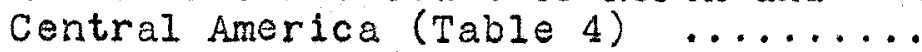

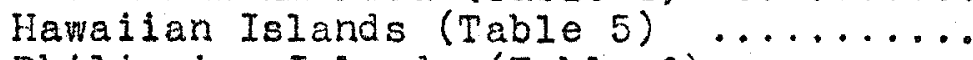
Philippine Islands (Table 6) .........

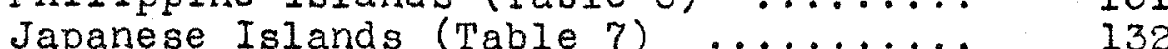

BIBLIOGRAPHY $\ldots \ldots \ldots \ldots \ldots \ldots \ldots \ldots \ldots \ldots \ldots$

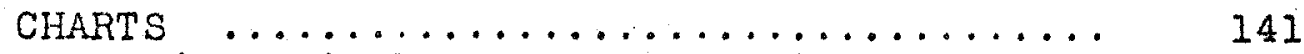

Marine animal sounds reported by

U.S. Submarines in the Pacific:

Winter distribution (Chart I) ........ 141

Spring distribution (Chart II) ....... 142

summer distribution (Chart III) ...... 143

Autumn distribution (Chart IV) ....... 144 


\section{SIGNIFICANCE OF SONIC FISH STUDIES}

The mariner of the Homeric fable heard a variety of sounds rising ominously from a sail-less sea. Recognizing that such a performance often preceded shipwreck, he interpreted it as the intended lure of evil spirits. Later Iisteners have not compared the babble to music, but rather to bellowing, purring, whistling and buzzing. Whatever its sonic quality, the fact remains that the probable "Song of the Sirens", if followed by a ship, might well have spelled disaster. For it could have been produced by great schools of shallow water elshes, "maigre" or "meagre" (Sciaena gquila), relatives of the West PacIf ic "nibe" (S.albiflora), which gather together during the breeding season and sw in shoreward over sandy bottom to spawn.

Early in the nineteenth century at the mouth of the River Cambodia, Cochin China, Ileutenant John White of the U. S. Navy (1824) reported extraordinary sounds originating below his ship, imaginatively compared to the united efforts of a deep-toned organ, jingling bells, a guttural frog, and an enormous harp. The natives assured him that the melée of sound was produced by fishes. 
"Therefore, joy or sadness, without a croaking of guchi, there can be no good catch for fishermen", comments a recent Japanese journal on conditions in the Yellow and China seas (Yamada 194I).

Throughout the literature of exploration and taxonomy there are similar references to noise-making marine forms, but not until world war II was the underwater chorus seriously considered. Much equipment developed during the war depends upon sound phenomena. Included are listenIng devices for the detection of nearby surface craft or submarines, mechanisms for firing mines and directing the course of torpedoes. The ir use, in some instances, was complicated by background noise not attributable to ship traffic or activity ashore. Wind, wave, and tide action were responsible to some extent, but much interference proved to be of blological origin.

Subsurface listeners described unldentifiable contacts running the gamut of sound from mild beeping,clicking, creaking, harsh croaking, crackl ing, whistling, grunting, hammering, moaning and mewing, to the staccato tapping as of a stick rapidiy and steadily drawn along a ploket fence, of coal rolling down a metal chute, the dragging of heavy chains, fat frying in a pan, simulated propeller noises and the pings of echo ranging. 


\section{PROCEDURE}

It was obvious that animal noises were being encountered, but data were not immediately available to. explain the records or to predict where and when they wight again occur. That many of the sounds varied with changes of season,time of day, and environmental cond1tions became evident as well. Accordingly war research agencies instituted investigations of marine noise-makers, especially the quality and quantity of sounds produced.

Investigators made recordings of sonic fishes in aquaria and experimental ponds to demonstrate their actual sounds, the approximate pressure associated with the noise of each species, wave form and frequency characteristics. Other groups systematically made measurements of background noise in characteristic bays, harbors, and rivers along the middle Atlantic seaboard from Boston to Virginia, in the San Diego and San Francisco areas, the British Isles, Pearl Harbor, Hawail, and various other stations in the central and southwest Pacific. Some conclusions had immediate application to the planning and use of acoustic equipment, and data on the distribution of nolsy species assumed strategic importance.

The Japanese, experiencing the same baffling results with their inshore 1 istening devices, approached 
the problem later but in much the same way as American scientists. Underwater noises resembling enemy activity troubled submariners and threatened to render coastal controlled defensive minefields ineffective. In the summer of 1942, according to Admiral Aklyoshi (F1sh, 1946), the Japanese Hydrographic Department was asked by the Naval Experimental Laboratory to assist in a sonic experiment at Bungo Suido, where some submarine signal receiving stations were planned."N.E.L. had met extraordinary phenomena of nolsy sound which were sald then to be observed almost periodically - once in the evening daily ...... The results obtained were: (a) Causes still unknown."

During the next two years N.E.L.'s Submarine Sonic Laboratory at Numazu in Suruga Bay enlisted the help of Drs.Fujlwara, Hidaka, Takenouchi, and Mijaka, members of the Central Heteorological station. It was not until late in 1944, however, that Dr.Yoshio Hiyama, a prominent 1chthyologist of Tokyo Imperial University, who had been detailed by the Committee on Disturbance of Submarine Communication of the Japanese Research Council, "ascertained the cause of the noise to be vocal sounds, and frictional sounds in some cases, of groups of some kind of fish". Results of his study were supplied to the U.S.Technical Mission to Japan in 1946. 
Eighty-four disc recordings of sounds made by fishes, molluscs, crustaceans and marine mamals were brought to this country and have been studied in the present project.

From the standpoint of differentiation of animal sounds these records are disappointing. The carbon microphone, dipped in rubber solution, and amplifier " 6 W power, having $\mathrm{KX}-80, \mathrm{UZ}-6 \mathrm{C} 6$, and $\mathrm{UZ}-6 \mathrm{~L} 6 \mathrm{~A}^{\prime}$, which were, especially devised for this purpose, "could not endure the strength of coastal waves due to weak construction", (Hiyama, 1944). Thus experimental animals were confined in aquaria or floating cages. Such artifleial conditions impaired natural sound production considerably, and, except for the typical noises of feeding and warning, are almost useless. No animal sound analyses were tried by the Japanese.

Although far better results were obtained by the U.S.Naval Ordnance Laboratory, similar difficulties were experienced while studying fish noises with captive specimens. Experimenters at the Shedd Aquarlum found that imprisonment in tanks affected the fishes' sonic activity, both in character and volume. Nost of the species known beforehand to be sonic demonstrated their ability, but certain ones could not be induced to utter recordable sound. On the other hand, some species which were not suspected as sound-makers turned out to be comparatively noisy. 
Most unsatisfactory results under similar experimental conditions are referred to in a letter from Dr. W.M.Chapman (April 15, 1947): "All nolse makers among fish become silent after a few weeks in the steinhart Aquarium. We worked the tanks exhaustively last fall with an excellent microphone and got no results either day or night from any of several kinds of fish that we knew were noise makers."

One of the best sources of information on the reglonal distribution of biological background noise has been the narrative records of submarines engaged in wartime patrol. Many valuable records have been obtained from approximately 1000 of these logs reviewed in the present investigation.

The recorded sounds of probable animal origin have been charted on Pacific maps according to season (See Charts 1 to 4 ), and, wherever possible, a tentative identification has been included in the text under the DISCUSSION OF SONIC SPECIES (pp.13 - 107). Many records were attributable to whales and porpoises and have been treated in another paper, "Sonic Marine Mammals of the Pacific" (M.P.Fish, 1948). 
Emplrical data have also been obtained by personal correspondence and conference with many experienced ichthyologists.

The assembled observations, theorles, and experimental data, involving 42 families of fishes, have been combined in the present analyses, and will form a basis for proposed future field studies.

In some instances. it has been possible to apply data avaliable for particular species to other closely related forms. Although there are exceptions ${ }^{1}$, the organ responsible for the production of sound is generally quite similar in all members of a genus, and often of a whole family. For example, known sonic sclaenids Micropogon undulatus, Cynoscion arenarius, C.nothus, C.regalis, Bairdiella chrysura, and Leiostomus xanthurus have specially adapted air bladders and musculature (musculus sonificus). Knowing the function of the latter, it can be assumed that every species with similar anatomical relationships is a potential soundmaker. In the absence of fleld measurements for all sonic species, such a priori reasoning is necessary at this time.

IThe air bladder is usually large and complicated in Sciaenidae of American waters, but lacking in the genus Menticirrhus. Likewise, in the three closely related scombridae Scomber scombrus, pneumatophorus collas and P.japonicus, it is absent in the first but present in the second and third. 
The object of the present investigation has been to collect information on all marine animals known or suspected to be sonic. For each form two problems have been given special emphasis: first, the character and production of sound; and second, the animal's regional, seasonal, vertical and quantitative distribution.

Species have subsequently been grouped by type of sound produced, and by distribution throughout the region designated for consideration by the Pacific Oceanic Biology Project.

These analyses are intended to serve for:

1) Interpretation of hitherto unidentified background noises encountered by acoustic equipment in the sea; 2) Frediction of where and when subsurface biological noises may be expected; and 3 ) Formulation of a field progran for measurement of the sounds produced by pertinent sonic species. 
$D I S C U S S I O N O F$ SONIC SPECIES

All marine fishes for which sound production has been noted in reviewed literature have been considered in the following discussion. Because only incidental observations are available, many families do not seem worthy of more than brief mention at this time. However, for the sake of completeness, they have been included alphabetically with the more important families. Alphabetic rather than the usual taxonomic arrangement of families, genera and species, has been adopted in order to facilitate reference use by non-ichthyologists.

\section{ACANTHUR IDAE}

\section{Surgeonfishes; Tangs}

The common surgeonfish of the West Indies, Acanthurus hepatus, is known to make a stridulatory sound with the strong-spined dorsal fin. There is no evidence that the well developed air bladder participates in noise production. Its western Pacific counterpart, frequently referred to also as Acanthurus hepatus ${ }^{2}$, occurs in the coral reefs of Melanesia and the Philippines, and from

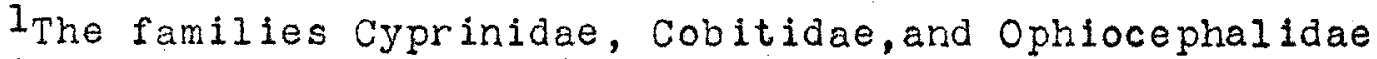
in which sound production has been reported in the fresh waters of Japan and the islands of the western Pacific have not been included.

2 Fowler uses the name paracanthurus theuthis.
} 
Mauritius to the East Indies. Species are extremely numerous throughout the region, and one, A.bleekeri, is a common market fish of the Philippines. Commercial size averages about one foot.

Sonic importance: Probably none.

\section{ANGU ILI IDAE}

True eels

Abbott (1877) describes the "distinctly musical" volce of a commón American eel. Its single note, frequently repeated, with slightly metallic resonance, is heard in the water only after dark, and sometimes on wet nights durine overland migration when the sound resembles the "faint squeak of a mouse".

Dufosse(1874) considers the characteristic sounds as "bruits de souffé", breathing or murmuring noises, originating from expulsion of air bladder gas through the ductus preumaticus and mouth.

Uchida (1934) Iists Angullia japonica among the sound-producing fishes of Japan. The species is of common occurrence between Hakodate and Nagasaki, and in Formosan waters, reaching a maximum length of about two feet. At least five species of Anguilla have been reported from Oceania, the Philippines and Japan, and hine 
from Indo-Australian waters. Although most of their lives are spent in freshwater, sexually mature eels are encountered migrating back to the sea to spawn.

Sonic importance: Probably none, for sound too weak to cause trouble, in spite of the eel's habit of curiously nosing into objects on the bottom.

\section{BALISTIDAE}

Triggerfishes

The triggerfishes are common in tropical seas, ranging northward only as accidentals. Although most species inhabit fairly shallow water, lurking around coral reefs, wrecks, etc., the young drift widely in ocean currents and occasional adults may wander some distance from shore, especially in association with floating seaweed.

At least 64 species of BAIISTIDAE have been reported from the Pacific area, including 27 of the genus Belistes and 13 of Balistapus, which are the two genera for which sound making has been described. Thirty-four species occur in Indo-Australian waters.

In 1879 Mosely wrote that Balistes "makes a curious metalif clicking noise by grating its teeth". The small terminal mouth, with a single series of more or less projecting, incisor-like teeth set in powerful jaws, would 
explain such an observation. The fact that some triggerfishes grow to nearly three feet and are known to crunch pieces of coral and to extract the soft parts of molluscs by boring holes in the shell, suggests inevitable and considerable noise production.

Harsh sounds resulting from the grating together of the pharyngeal or gill-teeth are reported by Norman (1931). Navy investigators in 1943 made sound recordIngs for an aquarium specimen of the common triggerfish Balistes capriscus, of the Florida keys.Rasping, spitting and hissing nolses can be heard on these records as a meal of smelt heads and shrimp is consumed, and similar sounds, presumably of pharyngeal teeth origin, indicate the specimen's annoyed reaction when prodded by a stick, which it thereupon tried to attack.

A third stridulatory organ attributed(Br1dge, 1904) to Balistes is the anterior dorsal fin. Sudden dropping of the much enlarged first spine, when released from a locked position by deflexing the second spine (a device which gives the triggerfish its name), might well be audtble, especially in large specimens.

A fourth method exhibited in the triggerfish fam11y, reported (Bridge,1904) for the genus Balistapus, 
concerns the bones of the pectoral arch, namely stridulation between the postclavicles (small bones attached to the posterior end of the clavicle and extending downwards) and a longitudinally grooved area on the inner surface of the cleithrum (a bone external to and beside the clavicle). With all stridulatory sounds the air bladder may act as a resonator.

Still a fifth alleed means of sound production (Schultz, 1948) is the use of the pectoral finrays as "drumsticks" on a taut membrane lying just behind the pectoral fins and above the air bladder, which acts as a resonator for the bladder in like manner to "the skin of a drum".

Balistapus aculeatus, the "drumming triggerfish", as indicated by its common name, makes a sound resembling the beat of a drum. According to Möbius(1889) and Bridge (1904) its source is stridulation between the postclavicles and the longitudinally grooved inner surface of the cleithrum, as described above for this genus. The air bladder is closely associated with this apparatus so that "the sound produced by friction is apparently strengthened by the transference of the vibrations to the walls and gaseous contents of that organ. The passage of the vibrations to the surrounding medium is facilitated by the fact that for a portion of their extent the lateral 
walls of the air bladder are in contact with the superficial skin, which visibly shares in the vibratory movement of the bladder when the characteristic drumming sounds of Balistes are being emitted" (Bridge, 1904). The characteristic sound of this species is described by Vernon $\mathbb{E}$. Brock (letter of March 23,1948 ) as a "grunting and a heavy humming noise".

An additional sound, a metallic click, was observed by Uchida (1934) during the feeding of a 30 millimeter specimen in a glass bowl.

Range: of very general distribution from the coral reefs of the Indian Ocean to Hawail. Reported from Test Africa, Red Sea, Zanzibar, Hozambique, Mauritius, Seychelles, East Indies, Queensland, Fhilippines, China, Melanesia, Micronesia, Polynesia and Hawail. Particularly common at Samoa; also at Johnston, Fiji, Guam, New Guinea, Marcus, and New Ireland islands. Japanese records from Okinawa, Ryukyu, Shikoku, and Okada.

Size: Reaches a length of 9 to 10 inches.

Balistes niger, which ranges the Japan coast from Hokkaido to Nagasaki,can produce a short, "snoring" sound, according to Uchida (1934), and accompanying vibrations are evident. 
Balistes vetula, the common "old wife" or "old wench" of the West Indian region, uses the alr bladder as part of the sound-producing mechanism in the same manner as B.aculeatus, according to S申rensen (1895). Although not of the Pacific fauna, this triggerfish is mentioned because it has been recorded from India and is closely related to the 22 species of Pacific Balistes.

Range: Primarily limited to the tropical Atlantic, very abundant in the west Indies and occasional as far north as Woods Hole. Occurs also on coast of India. Size: Reaches a length of lis feet.

Sonic importance: Probably slight, but possible because of large size of some individuals, with powerful jaws adapted to crunching coral and shells. To be expected in numbers about reefs everywhere throughout the region; although no evidence of schooling.

\section{BATRACHOIDIDAE}

Toadishes

The batrachoids are carnivorous inhabitants of coastal waters, mostly of the warm seas. Bottom fish of sluggish habits, they ordinarily hide under rocks, rubbish or weeds close to shore, although some species are dredged up to 40 fathoms. 
Ten genera, represented by 21 species, occur in the Pacific area. Of these, 10 species have been recorded on the coast of America from California to Peru. Only one, Porichthys notatus, ranges northward to Puget Sound. A single species appears in the Philippines. The other 10 toadfishes are restricted to Indo-Australian waters. None are listed from Japan and the oceanic islands of the Pacific.

Only two genera, Opsanus and Porichthys, have so far been reported sonic. Distributional records for Opsanus in the Pacific are limited to Australia and New Zealand, and for Porichthys to the American coast from the Canadian border to northern South America.

The fact that Opsanus croaks when handled, or grunts like some of the sculpins, has often been noted, but not until recently was the noise definitely analyzed. The results of observations on the Atlantic species 0. tau are included here for it is the only member of this family for which accurate sonic measurements are avallable. Very probably Pacific toadfishes will be found to react similarly.

Early experiments attempted, by annoying and frightening 35 aquarium specimens of $\underline{Q}$.tau, to induce soundmakine under water, but results were negative. Later however, (N.O.L.R NO.880), in its native habitat at Beau- 
fort, N.C., on a shelly bottom at a depth of 10 feet, a more accommodating toadfish made possible excellent recordings. Sound pressures reached 250 dynes $/ \mathrm{cm}^{2}$ in the 150 to 300-cps octave, when close to the hydrophone. The noise is described as an "intermittent, low-pitched musical blast of about 1/2-second duration, somewhat similar to a boat whistle, and is concentrated at the lowfrequency end of the spectrum". A hooked individual was heard under water to emit a second noise, " a raucous grunt of about the same intensity, duration, and pitch, but of different quality".

The characteristic vocalization, as described for a species of Porichthys (Greene, 1924) originates in the air bladder, which is U-shaped and divided by a transverse diaphraga. When unequal pressure is exerted on the gases of the two chambers, resulting from contractions of heavy muscles in their walls, this diaphragm is set in vibration and sound occurs.

Porichthys notatus, the California singing fish,midshipman,cabezon, or sapo, is the only Facific toadish whose sonic achievements have been widely publicized and scientifically studied. The sound is variously described as a low growling, croaking, grunting, humming or singing. Dr.m.F.Thompson (letter of April 10,1947) likens the sound 
to a "badly hurt and groaning man". Tone pitch and quality apparently vary in individuals to such an extent that different specimens in an aquarium can be recognized.

The sound apparatus has been carefully dissected and described by Greene (1924). In the adult the air bladder is U-shaped, with a well developed striated muscle mass on the outer side of each of the two limbs, enervated by the thickest ramus of each vagus nerve. Near the base of the $U$ is a transverse membranous diaphragm separating the cavity into an anterior and a posterior chamber with only a tiny opening between. When the air bladder muscles are contracted, the sudden unequal pressure of the gases of these two chambers causes the diaphragm to vibrate and characteristic humming sounds are produced.

Observations in connection with the above studies Indicate that hoise production is used "under conditions of colony activity - fright, combat, defense and friendly association".

Range: Recorded from southern Alaska to the Gulf of California, living near shore to the north but in deeper water (up to 62 fathoms) southward. From Point Conception northward, inshore migration to within tidal limits along reefs during the breeding season, in late spring and early summer; offshore migration into comparatively deep water in fall and winter. 
Size: liaximum length about 15 inches.

Sonic importancel of family: Probably considerable. Species very numerous on warmer Pacific coasts except in Japan and Oceania.

Following preliminary experiments on Atlantic toadfish (N.O.I.P.NO.880), Navy investigators concluded that the family might indeed have considerable effect upon underwater acoustic mechanisms. For instance, it is conceivable that a single noisy toadfish, following its tendency to seek refuge beneath submerged objects, might happen upon an acoustic mine. Should the latter have proper response characteristics, accidental firing could result.

\section{BROTUL IDAE}

Brotulid eels

Family Brotulidae includes a large number of genera widely distributed through the deeper parts of the sea. Many species have been taken off the Pacific coast of Middle America between Southern California and the Galapagos, from moderate depths to over 1000 fathoms. In the Philippines 17 genera have been recorded, and nine in Japan.

$I_{\text {See pp. }} 111$ to 112 for further discussion. 
only for Lucifuga subterraneus, a degenerate form Iiving in the cares of southern Cuba, has sound production been noted. Bridge (1904) considers the air bladder and associated muscles responsible. Its air bladder is large, rounded behind, and attached to the base of the skull.

Whether sound production is a compensation for sight, as suggested by various writers, and limited to this blind species is unknown. We can say only that other brotulids have large air bladders, sometimes with two posterior horns (e.g. Brotula), which suggest the ability to make sound. At least four species of the genus Brotula occur in the East Indies, Japan, Melanesia and Hawail. Sonic importance: Probably none.

\section{CAPROIDAE}

Boar-fishes

As with the Gasterosteidae and Triacanthidae, members of this rather deep-water family use the dorsal and pelvic fins for stridalatory noise-making. Such observations were reported by Bridge (1904) for Capros aper of the Mediterranean and Atlantic.

The derivation of the name capros is from the Greek "a grunting fish". This descriptive term, coupled with the fact that the boar-fish has a large air bladder, sug- 
gest that more is involved in sound production than $f$ in stridulation.

Capros australis is recorded from Indo-Australian waters, and several species of related Antigonia from the Philippines, Japan, and Hawali. The latter genus lives in about 100 fathoms, and grows to a length of at least one foot.

Sonic importance: Probably none.

\section{CARANG IDA로}

Pampanos, Jacks and Amberjacks

The carangids are a diversified tribe, widely distributed and largely oceanic. Strong, swift swimmers of temperate and tropical seas, they may stray into northern latitudes in connection with warm currents.

Of the several hundred species known, 220 are reported from the Pacific area, representing 27 genera. How universal sound production is among them cannot be stated, but the ability is recorded for certain species of the following genera: Caranx (of which there are about 75 species described from the Pacific), Selene (3), Trachinotus (12), Trachurus (7), and Vomer(2).

Various sounds have been ascribed to these fishes, especially the harsh grating of upper and lower pharyngeal 
teeth and the clicking of dorsal fins. In addition most species that are reported sonic are said to "croak continuously" or "grunt like young pigs", sounds which suggest air bladder particlpation.

Caranx equula, a common crevalle of the Japanese coast between Tokyo and Nagasaki, produces a "clear squeaking sound when taken out of water",according to Uchida (1934).

Caranx hippos, the horse crevalle, caballa, hardtail, jack, runner or toro, is better known as a nolsemaker. Observers agree that its "croaking" is harsh and often uninterrupted, the result of stridulation of pharyngeal teeth. A large, active fish of carnivorous habits, the seraping of upper and lower patches incident to eating may well seem almost continuous. Undoubtedly the air bladder acts as a resonator in the manner described for the Pomadasyidae. (See page 63). Burkenroad (1931) observed that when the air bladder was deflated, the sound produced by $\underline{\text {.hippos }}$ was "fainter" and "dryer" than in normal individuals. That this specles will grunt like a young pig upon capture, and repeat the sound whenever moved thereafter, as long as vitallty remains, was noted earlier by Bridge (1904). Apparently the sound may be produced accidentally during 
the process of eating, and more or less voluntarily as an emotional reaction. Nothing is known of its spawning habits, but it is possible that sound production may be associated there as well.

The horse crevalle has a wide range in warm seas. It is abundant on both coasts of tropical America,northward to Massachusetts in the Atlantic and to the Gulf of California in the Pacific, and in the East Indian region. The abundant species of the Indo-Australian Archipelago, referred to as E.sexfasciatus and apparently synonymous with C.hippos of Pacific writers,occurs from the Red Sea, Wuscat and East Africa to Japan, and throughout Oceania; especially recorded from Samoa, Fiji, Tahiti, Java, Sulu, Guam, Apia, Vanicola, Waigiu, Hawail,Philippines,Gilbert, Marshall, Ellice, Society and Caroline islands, offshore and in brackish lagoons, even entering rivers. The latter migrations have been the undoing of $\underline{C}$.sexfasciatus in the Philippines. Whereas in 1931 the species abounded in Batangas and Mindoro Provinces, ten years later (Roxas and Agco, 1941) it was on the verge of extinction because of dammed waterways preventing return to the sea. Almost everywhere abundant in coastal waters of its range, the horse crevalle usually welghs less than three pounds, but 20 pound specimens have been taken. Sound production has been observed for the moonfishes Selene vomer and Vomer setipinnis, which are re- 
corded from both coasts of troplcal America. Following H1ldebrand(1946) these names are reserved for the AtIantic representatives, and Selene brevoortil and Vomer declivifrons are used here for the species in the Pacific. Selene brevoortil, the moonfish, look down, or horsehead, is another carangid which, upon capture, is said to "grunt like a young pig" as a result of air bladder resonance. Since its diet consists of crustaceans and $\mathrm{fish}$, pharyngeal stridulation is probably very audible under water. Sound production would seem thus to be accidental as well as a possible defensive reaction. Whether sound is associated also with spawning habits is not known.

Range: Very abundant on the coasts of tropical America, especially on sandy shores from Lower Callfornia to Peru.

Size: Maximum weight, two pounds; length 10-12 inches.

Trachinotus paloma, a long-finned pompano, was used for sound recordings by Navy investigators. Grinding and clicking nolses registered on the discs were attributed by them to the hitting together of dorsal fins. Although this method of stridulation has not been previously reported for a carangid, it is used by such widely different fishes as certain triggerfish, snipefish (Centriscus scol- 
opax),boarfish (Capros aper) and the three-spined stickleback (Gasterosteus aculeatus).

Range: Known from Lower California to Peru. Size: About one foot.

Vomer declivifrons, moonfish, dollarfish, horsefish, sunfish or bluntnose, is another species that is heard to scrape together upper and lower pharyngeal patches thus producing an almost continuous rasping sound, similar to Caranx hippos. Like other sonic carangids, it is a large-mouthed carnivore that might be expected to exhibit noisy eating habits. No data on its spawning are available.

Range: Common on the Pacific coast of tropical America from Cape San Lucas to Peru. Size: Maximum length, nearly a foot.

Trachurus japonicus, the saurel or horse mackerel of Japan, makes a harsh grating with its pharyngeal teeth, as indicated in two recordings by Hiyama (Japanese record $X-4 O(N)$ ) made while feeding on the arthropod Mysis. 7. Saita of the Fusan Fishery Experimental Station observed a low-pitched sound made by this species in August 1931 in the Yellow sea (Uchida, 1934). In the same region in July 1933 Uchida (1bid) reports a low "snoring" 
accompanied by quick vibrations of the body immediately behind the pectorals, and short stretching movements of the lower jaw. He concludes that the noise is created by friction of pharyngeal teeth, and that the body vibrations result from air bladder vibrations. Bridge (1904) remarks on a special adaptation in members of this specles, but can offer no data on its origin or morphology: "This teleost has no true pneumatic duct, but instead a special duct which passes from the bladder to open into the right branchial cavity by a very minute aperture." Range: Called variously Caranx trachurus, Trachurus trachurus, .trachurus japonicus, or I.japonicus, reported from nearly all warm and temperate seas, including the seas of Japan, the Indian Ocean, both sides of the Pacific and Atlantic Oceans, and the Mediterranean. Size: Length about one foot.

Sonic importance: Questionable. Some individuals large and apparentiy noisy, but no evidence to date of concerted action by numerous specimens. 


\section{CEFHALACANTHIDAE}

Flying gurnards; flying roblns; batfish

These grotesque species, suggestive of both the true flying fishes (Exocoetidae) and the true gurnards (Triglidae), are equipped with an air bladder divided into two lateral parts,each with a large muscle. Bridge (1904) gives credit for sound production to this air bladder apparatus, and also to a hyomandibular bone modifled for stridulation ${ }^{1}$. The nature of the sound is not stated.

Production of sound by Dactyloptena orlental is when it vigorously opens its gill cover, was reported in 1857 by Müller, verified in 1884 by Sørensen and attributed by the latter to friction of the upper jaw and skul1. Uchida (1934) comes to the same conclusion. The species occurs through southern Japan, the East Indles and Hawail.

There are at least four genera and seven species of flying gurnards reported from the Facific region.Cephalacanthus has so far been restricted to the East Indies, Ebisinus to the Molucca and Fhilippine seas, and Daicocus to the seas of Japan. Dactyloptenus (Dactylopterus) has a wide geographical range from South Africa,Mauritius, East Indies, China, Japan, Melanesia and Polynesia to Hawail. Sonic importance: Frobably none.

IJordan and Richardson (1908) describe: "intermaxillaries with well-developed ascending pedicles gliding into the cavity between the anteal and prosethmoids." 


\section{CLUPE IDAE}

\section{Herrings}

Writers of a century ago described a shrill note somewhat like that of a mouse when a "herring" I was caught by the gills and Iifted out of water.

As with a number of other families (1sospondylous (ishes), the air bladder is connected with the oesophagus in the adult. In certain species the air bladder has a pair of caecal appendages extending forward to the head, sometimes coiled. Such anatomical structures suggest sonic capabilities, but the absence of further observations casts doubt on the production of much sound. However the possibility that some of the larger related forms might be sonic, warrants consideration. (For instance, the milkfish Chanos chanos and the tarpon Megalops cyprinoides, which grow to large size, belong to families closely allied to the herring.)

Many species of herring-like fishes are widely distributed throughout the region from Indo-Pacific waters to China, Korea, Japan, Philippines, Hawail, and the American coast from Peru to Alaska. The majority of herring live fairly near shore, sometimes entering estuaries. Mostly gregarious, they swim in enormous schools. Such concentrations occur in Japanese waters and southward through the Philippines and Malay Peninsula.

\footnotetext{
${ }^{1}$ species unknown.
} 
The most common Japanese sardine, Sardina melanosticta, frequenting water of $12^{\circ}$ to $25^{\circ} \mathrm{C}$, ranges from Kyusyu to southern Hokkaido on both coasts of Japan, the Ckhotsk side of Hokkaido in the north, and the east coast of Korea. Hone are found in the Inland sea or on the west coast of Korea. A neritic form, it stays within 15 miles of the Japanese coast on the facific side, and withith 30 miles in the sea of Japan.

The most comnon American form, Sardinops caerulea, commonly called pilchard or California sardine, ranges from the Gulf of California to Alaska, with adult concentrations in the California area between fall and spring, and in the northern region during summer and early fall. Maximum spawning occurs from Foint Conception to San Diego between liarch and June in water of $14^{\circ}$ to $18^{\circ} \mathrm{C}$. Other centers of abundance of large fish, as indicated by commercial catches, are Monterey to San Francisco from August to karch, and southern oregon to northern Vancouver Island from June to October.

Sonic importance:l Probably negligible. In view of the great numbers fished commercially, it is significant that no sound-making has been reported, however this and closely related families warrant investigation.

$I_{\text {See }}$ pp.112 to 113 for further discussion. 
COTT IDAE

Sculpins

The sculpins constitute one of the largest and most diversifled of fish families. Great numbers frequent rock pools and the shores of northern regions, some are restricted to fresh water, and other marine forms descend to considerable depths. Sixty-eight genera, including 121 specles, have been catalogued from northern Japanese waters and the Pacific coast of North America, and a single species from the Philippines.

Four eastern Pacific genera are reportedly soundmakers. No records are available for the western Pacific, but the great abundance of a family known elsewhere to be sonic, render it an important potential throughout its range.

The cottid head is typically broad and depressed, with one or more prominent spinous processes on the upper angle of the preopercle. In only a few genera is the head wholly unarmed. When a fish is disturbed, the head flattens and widens perceptibly, so that the long preopercular spine slants up and back at an angle of $45^{\circ}$. At the same time a low drumming can be heard. (Nichols and Breder, 1926). Since there is no air bladder, most observers agree that the sound results solely from the rubbing of the gill covers against the side of the body. 
Bridge (1904) reports the preoperculum of the bullhead Myoxocephalus scorplus modified for stridulation. Bigelow (1924) states that the bullhead, as well as the longhorn sculpin M.octodecimspinosus,"grunts or gurgles when drawn out of water, particularly when handled, and it is also known to grunt in the water". Dr.L.P.Schultz (letter of March 10, 1947) comments on the sculpins of Puget sound that "vibrate the opercular apparatus". Such sound-making was observed in Aspicottus, Enophrys, Leptocottus and others.

Aspicottus bison is very abundant along our Facific coast from San Francisco to Sitka, reaching a length of 12 inches. A.taurinus is described from Monterey Bay.

Enophrys claviger is a northern species inhabiting the Bering Sea region, taken at depths of 7 to 10 fathoms.

Leptocottus armatus ranges from San Francisco to Kodiak in inshore waters.Reaching a length of 12 inches, it is the most common of Pacific coast cottids. Of I.armatus, Dr.J.I.Hart (letter of March 24, 1947) states: "This fish produces a vibration in its throat when landed which is just at the lower threshold of audibility and can be better felt than heard." 
Myoxocephalus is represented in the Pacific by 12 species: M.axillaris, Bering Sea and Arctic Ocean; M.edomius (12-18 in.), Edomo and Hakodate, Hokka1do; I- jaok, Bering Sea in shallow water, very common to Amur River (Okhotsk Sea) and Sakhal in in the west and Unalas-

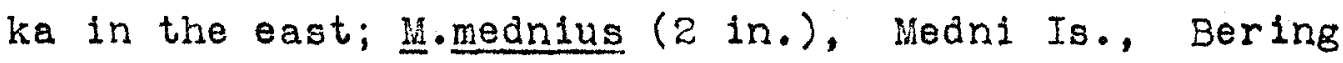
Sea; M.niger, Pribilof Is., very abundant in crevices of black lava rocks of St.Faui and St.George, fairly abundant about lhedni and Bering, of the Commander group; $\mathbb{M}$. nivosus (over 15 in.), Kuril Is, and Okhotsk Sea; H.parvulus, Medni Is., Bering Sea;M.polyacanthocephalus, Alaska to Kamchatka, abundant Bering Sea to Puget Sound, especially tide pools of Karluk, Kodlak and Aleutian Is.; M.ranimus, northern Japan (especially Same, huroran, Oomori, Hakodate, Sakhalin); M.stelleri.(over 14 in.), abundant on western shore of Bering and Okhotsk seas; $\mathbb{M}$. verrucosus (at least 10 in.), Alaskan region (especially Plover Bay, Siberia, near Bering Strait, Unalaska, Sitka,Bristol Bay, Kings Is., Port Clarence, Litnik, in depths of 5 to 30 fathoms); - yesoensis, northern Japan (especially Hakodate).

Sonic importance: No evidence to date, but investigation recommended because of great abundance in North Pacific of a group known elsewhere as sound-makers. 


\section{DIODONT IDAE}

\section{Burrfish; Balloonfish; Porcupinefish}

Burrfish, inhabitants of all warm seas, produce a high-pitched, nasal, whining scrape by grating the incisor teeth either during or after inflation. Burkenroad (1931) reports on the sounds produced by the Atlantic Chilomycterus spinosus, a species closely related to $\underline{\text { Caffinis }}$ which is common from the Galapagos to Lower California, Hawail, and from Tokyo to Nagagaki. Nolsy grinding of upper and lower teeth is noted in Diodon holacanthus and D.hystrix by Uchida (1934).

"A clicking sound made by the teeth" was also observed by Vernon E. Brock (letter of March 23,1948) for D.hystrix in the Pacific. Each jaw of its terminal mouth is covered by a bony plate suggesting the beak of a bird, and in a three foot specimen the noise produced may be considerable. The body is moderately inflatable. This sluggish, bottom-Iiving $f$ ish is commonly found among corals and weeds in the tropical eastern Pacific north to Lower California, at Hawaii, and in the Philippines. Its length is about three feet. Closely related D.holacanthus inhabits the waters of the Philippines and southern Japan. Representatives of the burrfish family occur plentifully in the East Indies, Philippines, Japan, llelanesia, Micronesia, Polynesia, Hawaii, Galapagos, Panama, and Lower California.

Sonic importance: Probably none. 


\section{DOROSOMIDAE}

Gizzard shad

The gizzard shad Dorosome cepedianum was considered as a noise-maker by early writers, and Abbott (1877) compares the sound produced by landlocked specimens to the whirring of wind over a number of telegraph I1nes. Again it is likened to the deeper notes of a coarse string on an aeolian harp.

Relatives of this Atlantic coast species are found in Indo-Pacific waters, Philippines, China, Japan and Tahiti. Feeding commonly on organic detritus, they congregate in immense schools on muddy bottoms.

Sonic importance: Probably none.

\section{EPH IPP IDAE 1}

Spadefish; Angelfish

Sound production in Chaetodipterus faber, the very abundant spadefish of the South Atlantic coast which reaches a length of at least three feet, was first described by Burkenroad (1931) as the result of the vibration of specialized muscles in the walls of the air bladder. The thin-walled bladder, lacking internal partitions and loosely attached to the dorsal body wall, ends

Included under Chaetodontidae by Schultz (1948). 
anteriorly in two short caeca extending almost to the base of the skull, and posteriorly in two long tubular caeca extending some distance behind the visceral cavity. A deeply colored, compact muscle, flat and broad, is firmly attached to the under side of the posterior half of the air bladder, extending upward a short distance on the sides, and backward a short distance out on the caeca. "This patch of muscle may be observed to vibrate as the sound is produced, in a fish whose belly has been opened. If the swim bladder is cut open, sound production ceases, although the muscle may continue to vibrate."

The character of the sound is a faint drumming. Burkenroad reported a few specimens to produce a "grating croak" .

Closely related $\underline{C}$.zonatus is rather common southward on the Pacific coast from San Diego to Panama, reaching a length of two feet or more. Allied forms, Ephippus argus and E.orbis occur throughout the Indo-Australian Archipelago to China,Formosa and the Philippines.Although eseentially marine, Philippine spadefish often penetrate into brackish or freshwater inlets, where they are notorious scavengers. Specimens under 8 inches are captured by trap or Iine fishermen around lianila Bay.

Sonic importance: ${ }^{1}$ Probably negligible but worth investigating because of size and possible abundance in certain localities.

$I_{\text {See }}$ pp. 114 to 115 for further discussion. 


\section{GADIDAE}

Codf ishes

Bridge (1904) attributed sound production to the air bladder and associated muscles in certain gadoids, especially the cod, Gadus, and the haddock, Melanogrammus. In the common codfish, G.morrhua, the air bladder is divided anteriorly into a pair of caecal prolongations extending forward to the head, and often curiously coiled. The Alaska codfish, G.macrocephalus, differs little from the above species with the exception of a smaller air bladder.

It seems improbable that sound, if produced in the sea, is of great intensity or it would already have been noted on listening devices in regions where these species are particularly abundant.

Numerous genera are reported from Japan, the Okhotsk and Bering Sea areas, Alaska to Puget sound. Some occur along the American coast southward to the deep waters off Panama.A single species has been taken in the Philippines. The Alaska codfish is excessively abundant in depths of 15 to 130 fathoms in the Bering sea, its range extending from Hokkaido to the offshore banks of Oregon. The Alaska pollock, Theragra chalcogramma, likewise occurs in tremendous numbers over much of the same range, reaching a length of over three feet.

Sonic importance: 1 Perhaps negligible, but worthy

$1_{\text {See }}$ pp. 115 to 116 for further discussion. 
of investigation because of the vast numbers and large size of certain gadoids in northern regions.

\section{GASTEROSTEIDAE \\ Sticklebacks}

The sticklebacks are seldom more than a few inches in length, and inhabit brackish or salt water close to shore. Stridulation in the anterior dorsal $f$ in and at the base of the pelvicsl, was reported by Bridge (1904) for European specimens of Gasterosteus aculeatus ${ }^{2}$, the common stickleback of arctic and subarctic regions of Asla,America and Europe. Uchida (1934) observed a "rubbing sound... done with the large spines of pelvic fins" in Japanese specimens.

The family is restricted to the northern hemisphere, extending southward only to China and Japan, and to Lower California.

Sonic importance: None.

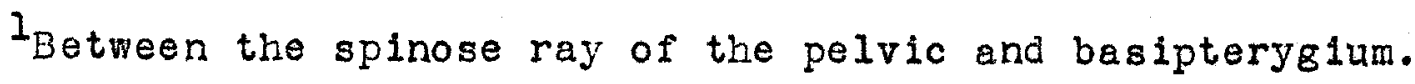
$2_{B 1 \text { gelow (1924) suggests that } G \text {.aculeatus and G.cataphractus }}$ "will probably prove to be identical". The latter species extends from San Francisco to Alaska and Kamchatka, and is very abundant northward. 
HEM IRAUPHIDAE

Halfbeaks, Balaos

Although the halfbeak famlly has been well known for more than a century, with over 75 species described, it was not until 1931 that its ability to produce sound was noted. In his studies on the marine fishes of Loulsiana, Burkenroad observed that an individual taken from the water vibrated its pharyngeal patches rapidly, at the same time emitting a rather loud click resembling the sound of a cricket.

Hemiramphidae are distinguished by unusual development of this region. An oval, slightly convex plate covered with blunt tricuspid teeth, formed by the fusion of the much enlarged third upper pharyngeals on either side, fits into a concave surface formed by the firmly united pharyngeals below. This unique apparatus in a fish that feeds chlefly on green algae may well have other functions beyond the grinding of food, and will certalnly produce sound. Another indication of the halfbeak's potentiality as a noise-maker is the very large, sometimes cellular, air bladder.

Members of the family are found everywhere throughout warm seas. Six marine genera, including 58 species, are recorded from the Pacific region. Host species stay falrly close to shore but a fow are pelagic. Like related needlefishes and flyingfishes, they swim at the surface, 
sometimes taking to the air. A halfbeak will skitter along the top of the water, raise the body until only the prolonged lower lobe of the forked tail is submerged, with which it skulls vigorously while keeping balance by outstretched pectoral fins. From this practise is derived the Spanish common name for the speciea,"balao" meaning "to dance". Certain fresh and brackish water genera (Dermogenys, Nonorhamphus, and Hemirhamphodon) are viviparous.

Hemirhamphus unifasciatus, the common halfbeak or skipjack, is the first species of the order synentognathi to be recorded as sonic. Burkenroad observed: "This animal produced a falrly loud, cricket-like stridulatory sound whenever it was lifted from the water of its container, apparently by the scraping together of the rapidly vibrated pharyngeal patches. These patches are opposable, and are covered with small, hard, firmly set teeth. The vibration of the pharyngeal region was synchronous with the production of sound".

Although this is the only record of its kind, 27 species of the genus Hemirhamphus have been listed from the region, all undoubtedly capable of similar stridulation. That hemiramphids gather in schools suggests the possibility of intense sound under certain conditions. 
Range: East Africa;British India; Sumatra; Java Sea; Java; Timor; Ambolna; Paclfic coast of Panama, as well as Atlantic coast of tropical America.

Size: Maximum length about one foot.

Sonic importance: Possible under certain conditions, al though improbable.

\section{HOLOCENTR IDAE \\ Squirrelfishes; Soldierfishes}

Air bladder and associated muscles of the common West Indian squirrelfish Holocentrus ascensionis are reportedly responsible for sound production (Bridge 1904). The family is characterized by a large air bladder, sometimes connected with the organ of hearing. Western Pacific species are numerous and widely distributed in the East Indies, Philippines, China, Japan, and the oceanic islands to Hawail, as well as the Pacific coast of tropical America.

Sonic Importance: Probably none. 


\section{LEIOGNATHIDAE I (GERRIDAE GÜNTHER PRO PARTE) Pouters and Mojarras.}

Although the pouters and mojarras are well known in the coastal waters of tropical seas, we have only two references to the fact that they may be sonic. In a Japanese journal Yamada (194k) includes Lelognathus argenteum (i.e.L.equulus) in a list of the "many soundmaking fishes in our country".

Uchida (1934) states that "friction of its premaxilla and frontal" is responsible for the production of noise in this species, as well as in other members of the genus.

As far as potential sound producing organs are concerned, an air bladder is present and in at least one Eenus, Eucinostomus, modified so that its posterior tip fits into a hollow cone formed by the enlarged second interhaemal spine. The mouth is exceedingly protractile in all species, and can be protruded into a tube directed horizontally, dorsally or ventrally. Teeth are absent on palatines, and quite feeble in the jaws.

For the most part small or moderate sized carnivores Inhabiting inshore waters, the Lelognathidae may prove to be important as noise-makers only because of the ir great numbers.

IFollowing weber and de Beaufort (1931) for Indo-Pacific species. 
The three genera Lelognathus, Gazza and Pentaprion are restricted to the eastern hemisphere where they occur throughout the Indo-Pacific region from the Red sea and East Africa to the oceanle Pacific Islands, Japan and China. A fourth genus, Gerres, is distributed over the same region and along the tropical coasts of the western hemisphere as well. Eucinostomus and Diapterus are confined to tropical America. Forty-nine species of these six genera are reported from the area under investigation.

Leiognathus equulus (synonymous with L-argenteus Lacépède) is accredited as a sound producer in Korean waters. In a paper translated from the Japanese, "sea Where Fishes Croak" "T.Yamada mentions this species along with croakers and other known sonic ilshes.

Range: Common throughout the Indo-Pacific region, notably from Madagascar, the Red Sea, the coasts of East Africa, India, Ceylon and Slam, north to the Ryukyu Islands; south through Formosa, the Philippines, Marianas, Borneo-Ceylon region, Sumatra, Java and Bali to Australia; and east through the Solomon and Fiji Islands to Samoa. Size: haximum length about 16 inches. Sonte importance: Doubteul. 


\section{MACRORHAMPHOS IDAE}

snipefishes

Macrorhamphosus scolopax, a nediterranean species of snipe-fish accidental on the Atlantic coast of North America, uses the anterior dorsal fin to produce stridulatory sound. A large air bladder is present.

Two closely related species of Macrorhamphosus are recorded from Japan, and another from Hawail in depths of 59 to 70 fathoms.

Sonic importance: None.

MOL IDAE

Ocean sunfish; Headfish; Mola

The ocean sunfish, which may reach a veight of two tons, grates its teeth in the manner of pigs and other ruminants. Fishermen have repeatedly observed that this amazing creature grunts and eroans as it is hoisted from the water. Whatever sounds are produced must be explained by stridulation. There is no air bladder and the belly is non-inflatable. Uchida (1934) claims the grinding of upper and lower teeth as responsible for the noises observed.

Three closely related genera, including four species, are found in the region under consideration. Although reportedly of world wide distribution in the open seas of 
warm temperate and troplcal latitudes, with various spocies frequent off the coasts of California, Hawa11, Austral1a, and Japan, Nichols (1945) notes that the ocean sunfish "seems to be rare or absent across the great breadth of the Pacific". In cooler waters stray individuals swim slowly or float on the surface, apparently chilled into partial insensibility, and, because of the ir size, may be seen for some distance. They are belleved sometimes to descend to great depths as well(Bridge 1904).

Mola mola, the common ocean sunfish, is known to make a grinding, pig-like noise. The terminal mouth is small, but the teeth are completely united in each jaw to form a bony beak without median suture. Stridulation between the upper and lower "plates" is wholly respons1ble for the sound produced. There is no air bladder to act as a resonator, and the belly does not inflate as in related swellfish families.

Range: Oceanic and cosmopolitan in most warm seas, from 8 fathoms to the surface. Common from San Francisco to Mazatian; occasional at Hawali and northward in the tropical West Pacific to Tokyo.

Size: Maximum weight recorded from Indo-Pacif10 waters, 4400 pounds. Maximum length from California, 10 feet 11 inches. Another Californian specimen: 8 feet 8 inches, 1800 pounds.

Sonic importance: Moderate. 


\section{MONACANTH IDAE}

Filefishes

The ability to produce sound has been ascribed to Monacanthidae by means of the air bladder, by dorsal in stridulation, and most particularly by virtue of specially adapted incisor teeth. (See Monacanthus setifer).

Hyama made a number of sound recordings for a Japanese filefish, in which he attempted to differentiate the nolses associated with feeding, swimming and capture. (See M.c1rrhifer).

Uchida (1934) singled out Canthigaster rivulatus as the principal sound-maker in the filefish family of Japan.

Ugually of small size, slugglsh herbivores content to drift with warm currents, most members of this family are not very important in the underwater chorus. However such species as the common yellow "Chlnaman" of Australla, Pseudomonacanthus ayraudi, which reaches a length of over two feet,might be expected to contribute appreciable noise. Only two species occur on the American Pacific coast, but the family is found throughout oceania from Hawali to Austral1a, and from the Cape of Good Hope to China and Japan. At least 44 species of 12 genera have been reported from the region. Eleven species of Cantherines and 15 of Monacanthus are represented, which are the two genera for which sonic records are avallable. 
Cantherines pardalis produces sound, according to Bridge (1904), by means of the alr bladder. No further details are given.

Range: Tropical Indo-Pacific, from Red Sea, East Africa and Cape of Good Hope to Malay Archipelago, Melanesia, Micronesia, Polynesia and western Australia.

Monacanthus cirrhifer was used by Yoshio Hiyama (Fish 1946) for fifteen sound recordings under the varlous conditions of feeding on Mysis, capture, and swimming about in an aquarium. Typical nipping and crunching indicated eating activity, and a somewhat similar faint "wick-click" was audible amid the thrashing of capture, as though the fllefish used the grinding of pharyngeal teeth in defense or alarm.

Range: Tokyo to Nagasaki; Easter Island.

Monacanthus setifer was identified by Günther as the East Indian form of H.hispldus. The latter has boen reported as sonic by means of the air bladder, by dorsal fin stridulation, and particularly by stridulatory ridges on the posterior surfaces of the two median pairs of upper incisors of the inner serles. Burkenroad (1931) observed the fish to slide the biting edges of the lower incisors over the sloping posterior surfaces of the upper incisors 
while opening and closing the mouth rapidy. A sharp, whining, scraping noise resulted.

Range: East Indies. The Atlantic form abundant on South Atlantic coast, straying from Cape Cod to Brazil. Size: Length about 10 inches.

Sonic importance: Frobably none.

\author{
HONOCENTR IDAE \\ Pine-cone fishes
}

A single species of this family, jonocentris japonicus, is known from the Philippines and the coasts of Japan between Tokyo and Nagasaki. Uchida (1934) reports stridulatory sound through the agency of the pelvic fins. Sonic importance: Probably none.

\title{
OPH ICHTHYIDAE
}

Snake eels

II iyama made several disc recordings of Ophichthus Indicating that he suspected the snake eel to be sonic. The records, as studied here, reveal little animal sound, however, beyond a possible low growling or grating under 
conditions of capture. If sound production should be found universal for the family, the catalogue of noisemakers would be considerably enlarged. There have been at least 21 genera and 115 species recorded from this area.

Although most of these abundant species are of small or moderate size, some attain three or four feet in length. The teeth may be pointed, confcal or granular, sometimes in uni- or biserial rows, but often massed in wide bands on jaws and vomer. Such dentition in a fish that feeds and scurries around the bottom might make even a single large individual troublesome to sonic equipment.

Ophichthyidae are very generally distributed in tropical seas but are most frequently encountered around coral reefs in depths of less than 100 meters. Some of the Indo-Australian species ascend rivers.

Ophichthus is represented in the region under investigation by at least 31 species. Hiyama fails to distinguish his sonic specimens beyond that they were captured in the vicinity of Misaki, off the mid-eastern coast of Japan. Thus they were probably one or more of the following Japanese species: O.asakusae, O.cephalozonus, O.evermanni, O.haber 1, O stenopterus, 0 .tsuchidae, Q.urolopus. 
Perhaps the noise produced is the characteristic breathing sound, "bruits de souffle",observed by Dufossé and others in Anguilla, mostly as a result of the expulsion of gas from the alr bladder through the ductus pneumaticus and mouth. Or there may be dental stridulation. The teeth of Ophichthus are conical, sharp, subequal without canines, in one or more rows on jaws and vomer, and grouped or in pairs on intermaxillary plate.

\section{Sonic importance: Improbable.}

\section{OPHIDIIDAE}

Cusk eels

The cusk eels of Europe are sound-makers through the use of the air bladder, which is constricted in such a way as to form a series of several intercommunicating sacs.

At least seven species occur on the coast of California and Lower California. One has been described from Luzon, P.I., and another from Japanese waters near Misaki and Sagami. The air bladder of the latter is short and thick, with a large foramen.Carnivorous fishes found in most warm seas, some cusk eels descend to considerable depths.

Sonic importance: Probably none. 


\section{OFLEGNATHIDAE}

The loros

This quite insignificant family is represented by a single genus known from Peru, the Galapagos, the Philippines, China, Japan, Australia and South Africa. There are just six species recorded from the region under consideration, none of them very abundant or of large size. All exhibit the unique jaw structure described below, suggestive of the beak of parrotfishes, and doubtless responsible for considerable noise since echinoderms, crustaceans, and gorgonians are included in the diet.

When gaffed, Oplegnathus fasciatus, the ishidai, continues to produce short and clear "snoring" sounds ("like dot-dot ... dot-dot") as it struggles violently (Uchida, 1934). Experiments with fishes under 375 mill1meters produced only weak sound.

The ishldai was listed again in 1941 by Yamada with other Japanese sonic fishes. During feeding it is probable that the sharp-edged small mouth, with fused teeth forming a plate in each jaw continuous except for a median suture, is a sound-producing organ. Such an apparatus would certainly seem capable of the clicking and grinding noises heard on two sound recordings prepared by Hiyama while experimental specimens were feeding. Range: Yokohama, Hakodate, Nagasaki. Sonic importance: Probably none. 


\section{OSTRAC IIDAE}

\section{Trunkfish; Boxfish; Cofferfish}

The Japanese trunkfish Ostracion immaculatum (closely related to 0 .punctatum of the eastern tropical Pacific), produces a grating sound by grinding upper and lower teeth, according to Uchida (1934). No other sound is mentioned by this author, but Pappe (1853) mentions the "Erowl" of Ostracion. On the basis of underwater observations with a diving helmet, Vernon E. Brock (letter of March 23, 1943) describes the nolse uttered by the Pacific species O. Sebae as"a heavy low vibration that can be felt by the hand when the fish is held as well as heard". Similar growling noises, well known for the tropical Atlantic Lactophrys trigonus, were attributed by Bridge (1904) to the air bladder and associated muscles.

Numerous species of Ostracion, Lactophrys and related trunkfish abound near the bottom in shallow waters of the tropical pacific, especially about southern Japan, Fhilippines, East Indies, Australia, Oceania, Hawai1, Galapagos and Clipperton Island. Small specimens of genus Arcana were taken by the ALBATROSS between 59 and 163 fathoms in Hawailan waters.

Sonic importance: Probably none. 


\section{PEMPHER IDAP}

\section{Catalufas.}

The catalufas are small fishes, usually inhablting rather deep water (to about $100 \mathrm{~m}$.) in the tropics. The ability to produce sound was first discovered by Uchlda (1933) for Pempheris japonicus, a species whose distribution is reportedly limited to the waters off Tokyo but which must occur in considerable abundance since it is Iisted as a "foodfish" there. Uchida (1934) observes: "A spear was thrust into a school of pempheris japonicus swiming in water approximately 5 meters deep near Jyogashima, Misaki. The speared fish suddenly produced two low pitched short snoring sounds consecutively, and the others in the school dispersed in all directions. When the author pressed on the side of the speared fish vibrations of the air bladder wall were detected as it produced the sound." The sound produced underwater was sufficiently loud to be heard above the surface.

The famlly is characterized by a large air bladder, thick and divided into two parts, the anterior section smaller and rounded.

Only the above species is reported in the fauna of Japan; three species of Pempheris have been described from the Philippines, five from Indo-Australian waters, and a single one from the Pacific coast of Mexico.

\footnotetext{
Sonic importance: Probably none.
} 


\section{PERISTEDIIDAE}

\section{Deepwater gurnards}

Although this family has not been reported sonic, Its close relationship to known sound-makers warrants inclusion here. All species have a simple air bladder.

of the three genera described, only two are reported from the northwest Pacific, represented by nine species. Two species inhabit the deeper waters around the Hawailan Islands, three species are included in the fauna of Japan, and three in the Philippines:Peristedion emiscus - Sagami Bay; P.engyceros - Hawaii, frequently taken in 165-469 fathoms but never in large numbers; $\underline{P}$. hlans - Hawaii in 70-362 fathoms; P.Ilorhynchus - East Indies and Melanesia; P.nierstraszi - Philippines; P.orientale - Japan, north to Tokyo;P.rieffeli - Southern Japan, Uchinoura Bay, Kagoshima, Urado, Tosa and China; E.welchi - Philippines; and Peristethus murrays Philippines.

There are several other families closely related to known sound-making gurnards, which are resident in the Pacific area, but in the absence of an air bladder they are not deemed worthy of consideration, even as potentials. 
They are: 1) PLATYCEPHAL IDAE - Flat-hoads.

About 40 species in Japan, north western Japan, Philippines, and all Indian, Polynesian and Australian seas to the eastern coast of Africa.

2) BEMBRIDAE

Three species in southern Japan, from Nagasaki to Tokyo.

3) HOPL ICHTHYIDAE - Needle-flatheads. Four species from central ano southern Japan, and two from Hawaii in 116 to 351 fathoms.

PETROMYZON IDAE

Lampreys

The great sea lampreys are described as roice possessors by C.C.Abbott (1877). Mating pairs of Petromyzon nigricans were observed to utter a peculiar sound, quite dissimilar to that of any other fish. Abbott noted the same noise when individuals were caught and taken from the water.

No species of Petromyzon are recorded from the Pacific, but another lamprey, Entosphenus japonicus, Bimi- 
lar to the large anadromous E.tridentatus which is common on our coast from Unalaska to Southern California, occurs throughout northern Asia and Japan.

Sonic importance: Probably none.

POMACENTR IDAE

Demolselies

These extremely active, abundant little reef fishes were first reported sonic by Uchida in 1934 , based on his own Observations near Ko-niya (Nansei Shoto) on July 27, 1927. "As it swam rapidly away among the reef corals the sound was similar to that produced by Therapon oxyrhynchus ${ }^{1} \cdot "$

Naval Ordnance Laboratory investigators made similar observations. Sound gear exposed in aquarla recorded loud clicking or rasping when food was offered, apparently indicating the noise of competition even more than that of actual eating. Drumming or tapping was spontaneously produced at other times, especially by individuals in pursuit of others. Both types of sound were thought to be the result of pharyngeal stridulation.

In pomacentrids the lower pharyngeals are united into a solid subtriangular plate; the second upper pair

Isound of this species not described, but apparently well recognized by fishermen. 
are distinct, the third and fourth united. Noisy gnashing of these bony, toothed parts, amplified by the air bladder, may well cause considerable underwater sound.

Photomicrographs were prepared and analyzed. In a tank of 35 foot-long garibaldi, Hypsypops rub1cundus, the recorded pitch was low with most of the energy concentrated in the 75 to 100-cps octave and pressure reaching 22 dynes $/ \mathrm{cm}^{2}$. For much smaller ( 3 inch) demoiselles, Dascyllus trimaculatus, pressure in the same band barely reached 6 dynes $/ \mathrm{cm}^{2}$.

Pomacentrids, because of their tremendous numbers in coral reef areas, may contribute appreciably to the general background noise, even though individually the sound is fairly feeble. Of the three genera so far reported sonic, there are in the region 14 species of Amphiprion, six of Dascyllus, and one of Hypsypops.

From the whole Pacific region there have been some 24 genera and 200 species described. About a dozen frequent the Pacific coast of tropical America;about twenty species are recorded from Japan, and the others are generally distributed throughout Oceania and Indo-Pacific waters. As a rule they are closely associated with reefs, but occasionally there are offshore records, as with 
Chromis dimidiatus taken in 233 fathom water of Kauai, Hawailan Islands, and Zabulon roseus whose habitat off the KeI Islands southwest of New Guinea is 129 fathoms.

Amphiprion polylepis (Amphiprion frenatus):eight specimens of the sea-anemone fish from the Fiji Islands exhibited a spontaneous tapping or drumming sound to Navy observers. Like all pomecentrids, an air bladder is present and the lower pharyngeals are fused into a solid bone, potential nolse contributors. There are strong conical teeth in a single series in both jaws.

The species is commensal with large anemones, nestling among the tentacles of the host and apparently immune to its battery of paralyzing stinging cells. The very small size and lone habits of this bottom-living fish render it of no sonic importance.

Range: Japan, China, Ryukyu, Melanesia, Micronesia, East Indies, Ceylon, Red Sea to South Africa. Size: Maximum length about five inches.

Descyllus trimaculatus (D.albisella):elght specimens of the single-striped demoiselle, in company with the sea-anemone fishes above,produced a similar tapping, drumming nolse of spontaneous origin. Pressure in the 75 to $100-\mathrm{cps}$ band reached 6 dynes $/ \mathrm{cm}^{2}$. 
The large air bladder and general pharyngeal formation is alike in the tro species and is probably responsible for the sounds observed. In Descyllus there is an outer series of enlarged conic teeth in the jaws, and an inner irregular biserial band of minute teeth as well.

Range: Hawail, Polynesia, Hicronesia, Melanesia, East Indies, India, Red Sea to Mauritius.

S1ze: haximum length less than $5 \frac{1}{2}$ inches.

Hypsypops rublcundus, the common garibaldi of southern California, showed itself to be a sound-maker worthy of consideration. Photomicrographs made from underwater recordings showed a long, low curve for the spontaneous tapping of pharyngeal teeth, changing to a "staccato" high frequency curve when food was introduced into the tank. Undoubtedly much noise recorded would be explained by mechanical crunching of shrimp, but investigators believed that harsh clicking was an indication of competition for food more than actual sound of eating. So loud were the sounds that they could be heard distinctly through an inch and a quarter of glass. Apparent pressures indicated by Esterline-Angus Recorders reached 22 dynes $/ \mathrm{cm}^{2}$ in the 75 to 100-cps octave.

Range: Common in clear waters about rocky 1slands from Pt. Conception, California, to Todos Santos Bay, Lower California. 
S1ze: Maximum length 14 inches.

Sonic importence: Frobably moderate, and warranting further investigation.

\section{POMADASYIDAE ${ }^{1}$ \\ Grunts; Grunters}

The long established common name for this family Indicates both its sonic ability and the quality of the sound produced. In all species an air bladder is present, usually simple, and the separate lower pharyngeals are armed with pointed teeth. The characteristic "grunt" is a harsh grating or rasping sound resulting from stridulation of upper and lower pharyngeal patches, amplified by air bladder resonance.

As described (Burkenroed, 1930) for a closely related Atlantic form, Heemulon plumieri, (- Conodon nobilis), these tooth-bearing patches are opposable. The upper pharyngeal patch is broader with more freely movable teeth, but the lower patch is flanked by similar hard teeth on the fourth Eill arch, thus making the upper and lower toothed areas equal in width. Lying against

$1_{\text {Family Pomadasyidae follows Fowler, Proc.USM } 100,}$ 11: $199-322$. 
the posterior bony edge of the lower pharyngeals is the swollen anterior end of the air bladder, which presses against the oesophagus.simple experiments blocking first one and then another of these adjacent organs, proved. that all participated in the typical haemulid "grunt". Disc recordings made by Hiyama in Japan for Pristipoma and Plectorhynchus indicate that these two genera are noise-makers.

Orthopristis chrysopterus, the hogfish, is a common grunt of the tropical Atlantic,very little differentiated from the five Pacific representatives of the genus. The spectrum of noise produced by a specimen in captivity at Beaufort reached 2.3 dynes $/ \mathrm{cm}^{2}$ in the 200 to $400-\mathrm{cps}$ octave (N.O.L.R.No.880). Although there are too many unknown variables to draw comparisons, it would appear that the intensity of hogfish sound exceeds that of the croaker. (As shown on p.72, under more or less similar experimental circumstances, the volume of 130 croakers was only 1.4 dynes $/ \mathrm{cm}^{2}$ in the 300 to $400-\mathrm{cps}$ octave.)

If other grunts are equally nolsy, as they doubtless are, Pomydasyldae must add considerably to the general background din of the deep. For the family boasts some 26 Pacific genera and 133 specles,many of them very numerous. Some species gather in enormous schools in the 
spawning season, and some reach three feet in length, which are important factors in sound production.

Mostly the grunts are shore fishes common along the rocky coastlines of all warm seas, but certain specles are found only in deep water in the vicinity of reefs. At night they are wont to move into shallower water in search of crustaceans and worms, which are the principal diet. Cold weather invariably drives them offshore into warmer, deeper water.

There are 32 species frequenting the warmer waters along the Pacific coast of the Americas, nine whose capture so far has been Iimited to the Indian Ocean west of Ceylon, and 92 which are of wide distribution throughout Oceania and reported often from South Africa to Japan.

Parapristipoma trilineatum, the isaki, mentioned particularly among the sonic flshes of Japan by Yamada, was used by Hiyama in the making of four disc recordings of underwater sound. Noises assoclated with feeding and capture were differentiated. It is apparent that the gnashing of pharyngeal teeth, with the air bladder possibly acting as resonator, is the method of sound production.

Range: China, Formosa, Japan. Size: Reaches about one foot. 
Pomadasys genus, which was among the first in which air bladder participation was observed, must be significant as a noise-maker because of the many species abundant in tropical seas.

Range: All tropical seas.

Size: Generally sme11, under 15 inches.

Sonic importance: Possibly appreciable, for

1) some species form enormous schools in spawning season,

2) some reach three feet in length, and

3) species are very numerous and widespread.

SC IAENIDAE

Croakers; Drums; Spots; Sea trouts or Weakfishes

Its wide range and apparent sound-making propensities have made sciaenidae best known of sonic fishes. The universal name "croaker" leaves no doubt as to the noisy reputation of most species. In some genera both sexes are known to emit a faint croaking by pharyngeal stridulation, but usually the male only is furnished with a specific drumming apparatus.l Accidental feeding noises are a

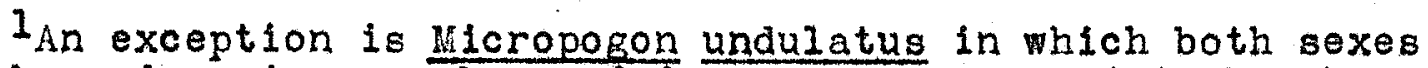
have drumming muscles and drum. Genus Menticirrhus has no drumming muscles or air bladder in either sex and consequentiy is silent. 
third source of sound production for many species have extremely heavy, pavement-like teeth and the jews are so powerfully muscled that the strongest shells of invertebrates can be easily crushed.

The peculiar sound associated with male sciaenids is possible through development of the air bladder, In certain cases to a complicated degreel, and extrinsic muscle attachments. A specialized red "musculus sonif1cus" is attached either directly to the bladder, or runs from the abdomen on each side to a central tendon situated above the bladder. By a series of rapid contractions (approximately 24 per second) the rigid, gas-illled air bladder is set into vibration and resonant"drumming" results. Such an apparatus is adapted to the production of rapidly repeated drums and rolls.2 The actual sound has been variously described as humming, hissing, purring, croaking, and whistling as well as drumming. Bridge (1904) reported that the noise of the Mediterranean maigre (Sclaena aquila) 18 meters below the surface was audible

IBridge(1904) studied the comparative anatomy of the air bladders of various sciaenids, observing variations from a fairly simple structure to one with 25 tubular extensions on each side, all of which soon subdivide into dorsal and ventral branches, then divide further ending blindIy or prolonged into a series of arches connecting with similar arches on the other side.

$2_{\text {Burkenroad (1930) calls attention, however, to the fact }}$ that the sciaenid Pogonias produces a similar rapidiyrepeated series of grunts although its drumming muscie is completely intrinsic to the air bladder, just as in the case of the searobin and toadfish. 
to an observer two meters above the water. The drumming occurs particularly during the breeding season, possibly as a signal for the congregation of schools.

From the time of Aristotle it was believed that the sound was in some way associated with the air bladder, but not until early in the present century was the specialized "musculus sonificus" noted and described in detail. Among the previously suggested mechanisms were:

1) Escape of air from the afr bladder through the pharynx (Agassiz, 1850).

2) Forcing of air from the air bladder into one of its lateral horns (Holbrook, 1860).

3) Muscular tone; the vibration of "most of the muscles, which, coated with aponeuroses, are in immediate contact with the diverticula of the air bladder". (Dufossé, 1874).

4) Pharyngeal teeth stridulation, coupled with

5) "Beating their tails against the bottom of the vessel in order to get rid of the parasites with which that part of the body is infested." (Günther, 1880).

$I_{\text {An amusing anecdote is told by Adams (1861) concerning }}$ Capt. Ward of the THUNDER, ly inE off Charleston, S.C., who had attributed mysterious sounds in the bottom of the ship to "insects in the spirit room", until a lady tea guet suggested the drumfish as a better explanation. 
6) Vibrations of the walls of the air bladder and of the air contained within, when set in motion by certain muscles(with the fascia of which it is connected.) (Sørensen, 1884).

Tower(1908) experimented on the air bladders of living drumfishes to demonstrate that the actual "drumming" and the "clapping together of the pharyngeal teeth" are sounds completely apart, thus refuting Günther. Likewise, with air and water filled rubber balloons replacing the gas-filled air bladder, he disproved both the Holbrook theory that drumming is the result of forcing air into one of the lateral horns, or that it is merely the result of muscular tone, as held by Dufossé and Sbrensen. These experiments proved to Tower's satisfaction that in sciaenid fishes the rapid contraction of the specialized extrinsic musculus sonificus, which produces vibrations of abdominal walls and organs, especially of the air bladder, is the complete drumming mechanism.

The loudness of sound is correlated with the degree of development in air bladder and drumming muscles. For instance, Lelostomus xanthurus makes a comparatively soft drum, probably due (Hildebrand and Schroeder,1927) to thinness of the air bladder walls and feeble development of druming muscles. 
The pitch is correlated with the length of air bladder, short species or small specimens with consequently shorter bladders producing higher-pitched sounds. Yamada (1941) points out that the sound varies suff1ciently so that different species of croakers are recognizable in Japanese waters. Both pitch and intensity of sound vary according to size of individual, the largest producing the loudest sound.

Burkenroad (1931) calls attention to a croak often concurrent with the drumming sound in certain sciaenids, which is the result of pharyngeal stridulation. Species of Micropogon, Stellifer and Bairdiella were observed to use the pharyngeals in this manner, whereas species of Cynoscion, Leiostomus, Larimus, Sciaenops, Pogonias and Menticirrhus did not.

Uchida (1934) states that the complex high and low-pitched sounds of Nibea manchurial and $\underline{N}$.japonica ${ }^{2}$ at a depth of 10 meters are sufficientiy loud to allow fisherfolk to thus locate the schools.

Although disturbance in surrounding water may cause sudden bursts at any time, the major volume of sound is synchronized with nightfall, and especially with the breeding season. National Defense Research

I Pseudosciaena manchuria

$2_{\text {Pseudosciaena japonica }}$ 
Council investigators in Calffornia reported a croaker chorus off Scripps Pler, La Jolla from 7:30 to 9:00 erery evening during the summer months. In the course of other early experiments on ambient background noise at various stations on the middie Atlantic coast as well as in the Sandiego region, croaker activity was noted as an important contributary factor.

Reporting on wartime observations in Chesapeake Bay Dobrin (1947) compares the peak of evening noise, when croakers were most active, to "a forge shop in full production. This analogy is more than a mere simile because the actual noise level was found to be considerably higher than would be registered by a noise-level meter in a typical forge-shop, being of the same order of magnitude as the noise emitted by an airplene motor 15 feet away. After the peak was reached, the level would die away as rapidly as it rose, and long before midnight the water became as quiet as it had been at noon."

The seasonal, as well as diurnal, cycle of croaker noise is noted (1bid) synchronized with the breeding migrations of the species. Beginning in late May as the first croaker schools enter the Bay, the recorded hoise (as well as the fishermen's catch) increases each evening, resching a maximum late in June, then gradually 
decreasing and finally disappearing about mid-summer. To all investigators it was evident that sciaenidae were among the principal noise-makers of American coastal waters, and, because of the ir great concentration in protected bays close inshore, must be reckoned with in the use of underwater acoustic apparatus. The Naval Ordnance Laboratory made preliminary sound recordings of various aquarium specimens of drumfish (the Pacific Roncador stearnsi, and the Atlantic Micropogon undulatus, Fogonias cromis, and sciaenops ocellatus), and later succeeded in obtaining spectra for the noise of the croaker,Micropogon undulatus, and the spot, Lelostomus xanthurus, segregated in experimental ponds at Beaufort, N.C. In spectra of background noise recorded inshore and offshore in the Chesapeake Bay region croakers were predominant. "In the evening, croaker activity reached a peak at the lower frequency end of the spectrum, usually at the 400 to $800-c p s$ octave. The magnitude of the sound level did not very greatly during the course of the measurements, ranging between 1 and 4 dynes $/ \mathrm{cm}^{2} \sqrt{o c t a v e}$ for daytime levels and up to 10 or 15 dynes $/ \mathrm{cm}^{2}$ roctave at night." (N.O.L.R.NO.880). Unidentified "drum rolls" 12 miles offshore in Chesapeake Bay (presumed by circumstantial evidence to be Cynoscion nothus) were considerably higher in pitch, 
with most of the energy concentrated in the 1600 to 3200 -cps octave and reaching a pressure of 34 dynes $/ \mathrm{cm}^{2}$, the highest background level ever recorded in this frequency region. (ibid).

Because of the many species, frequent large size and great concentrations of Sciaenidae along the sandy shores of most troplcal and temperate seas, the ir influence as sound-makers is considerable. At least 146 species of 32 genera are recorded from the Pacific region. Sound production is not universal, but all genera known to be particularly noisy are represented on the 1ist. There are at least 12 species of Cynoscion, and three of Micropogon, (two genera for which sound recordings of Atlantic representatives have been made.) Sciaenidae occur on the Pacific coast of the Americas, particularly about southern California and Panama, in abundance throughout the Indo-Australian archipelago, Fhilippines, Japan, China and Korea,but none seem to have penetrated to the oceanic islands east of New Guinea. They are inshore fishes, for the most part aroiding deep water or rocky bottom. A few species extend into relatively cool water, but none tolerate really cold water.

Skögsberg (1939) studied the nine specles of croakers in California waters. The following resumé of west coast sciaenids follows his paper. The spawning perlod is emphasized since it is coincident with schooling and prolonged production of sound. 
Cynoscion parvipinnis, the short-fin sea-bass, cannot be considered as important a noise-maker as its relative cynoscion nobilis because of fewer numbers and smaller size. During the summer spawning period, however, it undoubtedly contributes to the general background noise within its limited range.

Range: West coast of Lower California and in the Gulf of California.

S1ze: Probably not over two feet in length.

Cynoscion nobilis, the white sea-bass, is the largest sciaenid in California and potentially the no1siest. The large alr bladder has two anterior horns which are about three times as long as wide. Most of the pharyngeal teeth are small and pointed.

Range: Pacific coast from Victoria,British Columbia to the Gulf of California.

Size: Maximum length more than four feet, and maximum weight more than 90 pounds, although seldom over 60 pounds.

Spawning: April until August in southern California, with the height in llay and June.

Genyonemus lineatus, the kingfish, according to Skögsberg (1939) differs from other sciaenids of the Calffornia coast in its "as yet unexplained differential 
vertical distribution". Small schools may be common near the surface in shallow water, whereas in other localities 1t seeks a depth of 180 to 200 feet. Three-quarters of the total sport catch is reported from "deep sea fishing" parties outside the surf zone. The air bladder lacks anterior horns. Fharyngeals are well supplied with teeth, many of them enlarged, strong and pointed.

Range: Somewhat north of San Francisco to San quentin, Lower California, or possibly to Cerros Island.

Size: Naximum length about 13 inches, and weight 1 pounds.

Spawning: November until kay, with height in January, February and liarch (earlier than most west coast sciaenids).

Roncador stearnsi, the spotfin croaker or roncador, produces typical sclaenid drumming sounds in captivity, as evidenced by ivaval Ordnance Laboratory recordings. The species has a large air bladder, lackine anterior horns, and is reportedly one of the noisiest of the family. Lower pharyngeals are large, with many rounded molars and with viliform teeth in an outer series and in patches at outer corners.

Range: From Point Conception, California to the border of Mexico. Probably also on the west coast of Lower California. Fairly common along the southern California 
shore, sometimes occurring in great numbers. Shallow water fish, usually restricted to 20 to 30 feet over sandy bottom, but retreating into greater depths in winter.

Size: Fairly large, reaching about 19 inches in length, 7 to 10 pounds weight.

Spawning: Summer months, when it is most abundant in California waters.

Sclaena saturna, the black croaker, has been taken on rare occasions along the open California coast south of Santa Barbara, and on the bottom in shallow sandy bays.The air bladder is without horns. Some of teeth in both upper and lower pharyngeals are strong and large.

Range: Point Conception, Galifornia southward into the Gulf of California and west coast of Mexico.

Size: Haximum length about 12 inches.

Spawning: During the summer months.

Sciaena thompsoni. Thompson's croaker, has been described from Santa Catalina Island, southern California but is known from only the type specimen. 
Seriphus politus, the queenfish, is abundant during the warmer months in bays and along the open coast of southern California in 10 to 15 feet, rare in 30 feet of water. Dense schools can be seen around wharves and in shallow bays. In winter it doubtless moves of fshore.This is a comparatively small sciaenid, with simple air bladder pointed anteriorly.

Range: Coast of California and west coast of Lower California from San Francisco to the vicinity of Cerros Island.

Size: Maximum size 10 to 12 inches.

Spawning: Maturity reached in May with spawning throughout summer.

Umbrina roncador ${ }^{1}$, the yellowf in croaker, is a common year-round resident of southern California waters frequenting quiet shallow bays as well as the surf along open sandy shores in the warmer months, probably moving into somewhat deeper water in winter. The large air bladder is without anterior horns. Wany teeth of upper and lower pharyngeals are large and strong.

Range: Common from Point Conception, California, along the west coast of Lower California and into the Gulf

$1_{A}$ closely related species, Umbrina xanti, is known from Lower California to Peru and reputedly has "vocal powers well developed". 
of Calffornia. Reported capture from San Francisco questlonable.

Size: Maximum length about 16 inches, and weight over 5 pounds.

Spawning: During summer months.

The one remaining member of the family in California waters is Menticirrhus undulatus. Lacking an air bladder and therefore unable to drum, it has the distinction of being the only "voiceless" sciaenid. The pharyngeals resemble those of other genera, expecially Genyonemus, but Burkenroad (1931) advises that lienticirrhus does not use these bones for stridulatory nolsemaking.

As pointed out previously ( $p .73)$, there are no sciaenidae reported from the oceanic islands of the midPacific. Throughout the Indo-Australian region, however, they are well represented by six genera (Otolithes, Pama, Otolitholdes, Pseudosciaena, Johnius and Sciaena), and along the coasts of ChIna, Korea and Japan form an Important part of the fish population. (Collichthys,Otolithes, Pseudosciaena, M11chthys, Bahaba, Argyrosomus, Sclaena, Johnius, Wak and Nibea). Avaliable literature credits Collichthys, Nibea, and Pseudosciaene with the bulk of sound-making, but other genera are undoubtedly involved. Because this family must figure conspicuously in future plans for fish sound measurement in the western 
Paciflc, all available data on the more important species are included here, especially in re distribution, breeding season, and air bladder ldiosyncrasies.

Collichthys fragilis, the kandari or mebutokandari, is one of the common noise-makers of Yorean waters during its breeding season. Yamada (1941) records its activity in June in the oalm waters of some of the inner bays about moppo, and Yabe (1940-1941) from mid-liay to late June in the lower Kinko River on the Yellow Sea coast. $\left(36^{\circ} \mathrm{N} 126^{\circ} 4 \mathrm{O}^{\prime} \mathrm{E}\right)$

Range: West coast of Korea and southward in the Yellow, East China and South China Seas to Hongkong. Size: Slightly over 5 inches in Korean waters.

Collichthys niveatus, announces its spawning season by loud croaking in June and July around Hikin Yo, Korea. $\left(34^{\circ} 46^{\prime} \mathrm{N} 125^{\circ} 56^{\prime} \mathrm{E}\right)$.

Range: Around islands of Yellow, East China and South China Seas; Tyosen, Korea, further offshore than C. fragilis.

Collichthys lucldus is a small but noisy inhabltant of the east Asian coast. Its air bladder is slender, extending the length of the abdominal cavity, with about 20 pairs of arborescent appendages. 
Range: Common along the coasts of China and Korea to Manila, F.I.

Size: Four to eight inches.

Spawning: Way and June in the vicinity of Choushan Archipelago, China. ( $\left.30^{\circ} \mathrm{N} 122^{\circ} 40^{\prime} \mathrm{E}\right)$

Corvina japonica is a very common species on the fishing ground near the Chou-shan Archipelago in the East China sea. Its thlckwalled air bladder runs the full length of the abdominal cavity.

Size: Maximum about three feet.

The genus Nibea is very abundant in the seas of Chlna and Japan. As described by Yamada (1941): "Each Individual community seems to congregate on the bottom of the sea in 100,000 to $1,000,000$ and croak in unison. Then first the current in the bays begins to move, the sound is intermittentiy heard like the croaking of one or two frogs but as the movement (of the water) becomes faster the sound becomes louder and continuous. And at its highest, the croaking resembles the sound of a train passing over a bridge far away somewhere on an open plain, or the sound of a strong wind blowing through some bamboo grove. It can also be heard from any passing ship nearby." 
Uchida (1934) lists four species of Nibea among the prineipal sonic species of Japan. They are: N.albiflora, N.japonica, N.manchurica and N.schlegeli.

Nibea albiflore is distributed broadly from southwestern Japan to the China coast. Its very large air bladder extends the full length of the abdominal cavity, embellished by 14 pairs of arborescent, and three or four pairs of simple, unbranched appendages at the posterior end.

Range: East coast and Inland sea of Japan, especially about Osaka; Kyushu, Fusan and Zinsen, Korea; to Chou-shan Archipelago off the China coast; China.

Size: About 11 inches.

Nibea argentata, the guchi, was used sometime prior to 1941 for fish-nolse recordings in Japan, and a transcribed broadcast was given over Station JCAK, Tokyo. So loud is the croaking of this species when it migrates into shallow water during the breeding season, that fisherfolk drop their nets by following the sound.

Range: Yellow and China Seas, Japan, Korea, Indian Ocean, and East Indies.

Size: Average about 12 inches.

Spawning: End of April and first of Hay in the inner bays around Moppo, Korea. 
Nibea goma has a simple air bladder like other Nibea extending the full length of the abdominal cavity, with 20 pairs of side appendages. The one specimen described by In (1935) came from Shantung, China in the Yellow sea and measured about eight inches.

Range: Kyusyu; China Sea.

Nibea nibe, which is very close if not synonymous with $\mathrm{N}$.argentata, exhibited a one-chambered air bladder with 27 pairs of lateral appendages in an $11 \frac{1}{2}$ inch specimen from Chou-shan, China.

Range: Honshu, China sea.

Nibea sina has a simple, thick-walled a ir bladder extending the full length of the abdominal cavity,provided with 22 pairs of appendages. This croaker is common in the region about Chou-shan Archipelago, China.

Otolithes argenteus, reported by In (1935) from Kwangtung Province, China, has a simple, thick-walled air bladder similar to that of Nibea, extending the length of the abdominal cavity, with 40 pairs of lateral appendages. Specimens described were around 8 inches long $(6.7-8.27$ in.)

Pseudosciaena amblyceps is very common along the China coast. Its air bladder is simple, extending the 
length of the abdominal cavity, with 27 pairs of very small appendages. The striking seasonal differences between the northern area of the East China sea and the South China sea is demonstrated by the observations of Iin (1935) that this same species reaches its spawning condition off Cheklang in the East China sea between May and July, while less than five hundred miles to the south, off Kwantung Frovince, the season of sexual maturity is October to December.

Pseudosciaena crocea, püse (fusci), according to Yamada (1941), spawns from early June to late July around the Lalands near Moppo, southern Korea. As observed by this author, croaking begins as the school migrates into a shallow water breeding place. Its diurnal cycle is of great regularity, beginning about noon with "a weak, individual sound", soon reaching "a low-pitched sound of tremendous volume, like two repetitious volces singing to each other". By two o'clock the sound has become continuous, "more like the hustle and bustle of a metropolis. And finally, the volume reaches ... deafening sound during the flood-tide $(2-3: 00:$ P.M.). Around 5:00 P.M. the croaking abruptly begins to weaken like a receding wave, gradually becoming faint and finally, about 9:00 F.M. it completely stops". This time schedule seems to be affected only by tidal conditions. Yamada notes that there is "no 
croaking in a neap tide, and during intertidal period. Volume is in relation to force of tides".

"The sound made by pusse is the clearest, best suited for recording."

Range: Southern Korea; China Sea.

The species P.manchuria contributes its height of sound-making somewhat earlier from the end of April to the first of May, in the same locality. Uchida (1934) points out the synchronization of spawning season with helght of sound making.

Pseudosclaena indovittata is extremely common in the East China Sea around Chou-shan Archipelago. The air bladder lies the full length of the body cavity, with 24 pairs of lateral appendages.

Size: Average less than 10 inches. Spawning: End of March until the end of May.

Sonic importance: Considerable, because of frequent large size and great concentrations along sandy shores of most tropical and temperate seas. 
SCOMBRIDAE

Mackerel Family

The mackerels are a large and varied family ${ }^{1}$, for the most part streamlined, swift swimmers in the upper layers of the open ocean and deeper coastal waters. Because they are predators wandering characteristically in schools, and because individuals of some species attain great size, their noisemaking propensities could be of considerable importance.

Tower (1908) accredits the Atlantic Scomber brachyurus with the production of harsh grunts by rubbing together of pharyngeal teeth.

The close Pacific relative Pneumatophorus japonicus was singled out for sonic study by the Japanese (Fish, 1944) but no recording appeared among the discs acquired by the U.S.Technical Hission.

The family is of worldwide distribution in temperate and tropical regions, straying occasionally into arctic and antarctic waters. At least 40 species of 15 genera are reported from the area under consideration. Concerning the vast numbers present in the western Facific, Herre (1940)


(following H1ldebrand, 1946). Kishinouye (1923) divided the original scombridae into four families: Scombridae, the true mackerels; Thunnidae, the tunas; Katsuwonidae, the skipjacks; and Cyblidae, the sierras. The last mentioned group was further subdivided by Jordan, Evermann and Clark (1930) separating the wahoo as a fifth family, Acanthocybildae. 
states: "I have seen schools of Katsuwonis pelamis and Euthynnus yatto in the Philippines which would have fed everyone for a weok in a city as large as Manila or Seattle. But such schools are insigniflcant beside one of the oceanic bonito reported off the north coast of Oahu which was 90 miles long by 10 broad."

Pneumatophorus japonicus, the common saba of the western Pacific, because of its anatomical similarity to Scomber brachyurus, may be expected to produce the typical harsh grunts of pharyngeal stridulation, amplifled possibly by a well developed air bladder. In the genus scomber the a1r bladder is small or wanting, while in this spectes it occupies more than one half the abdominal cavity, thinwalled, fusfform, and pointed at both ends.

Range: California; Hawa11; Philippines; Mangs 1 Id.; New Caledonia; Japan. Common in northestern Pacific from Japan and Korea southward, and eastward to Hawail. Tremendously abundant.

Although we have no data on sound production among the larger members of the scombrid tribe, some, at least, may prove to be important. A few notes on size and range of the more important species follow. 
Acanthocyblum solandr1 - Wahoo. (Well-developed air bladder.)

Range: Tropical and subtropical seas, always near surface. Top of Southern California to Cocos Is.; Oceania; Philippines; Japan. Solitary, pelagic fishes, living offshore in such clear, highly saline currents as the Kuroshio. Size: Records to 12 feet in western Pacific; to 125 pounds in Hawa1j.

Auxis thazard - Frigate mackerel. (No air bladder). Range: Southern California to Mexico; Oceania; Sea of Japan; Atlantic. Size: Not over 5 pounds.

Euthynnus - Black skipjack; Mebachi; Oceanic bonito. Range: One species on coast of Lower California, Mex1co, and South America to Cocos Is. Another in Hawali, Philippines and Japan. Very abundant.

Size: California specimens to 12 pounds, but usually about 5. Average length in Philippines (E. 迆ito), about 16 inches.

Germo alalunga (G.germo, Thunnus germo) - Albacore (Air bladder running full length of abdominal cavity, narrow with a median swelling at anterior end.) 
Range: Pacific coast from Fuget Sd. to San Diego; Oceania; Jepan; Indian Ocean; Atlantic. From surface to depths of 45 fathoms in Japan, and 80 fathoms along the French coast. Recorded abundantly in June in open Pacific midway between Oregon and Hawail. Optimum flshing season In northern Japan waters from December to February (ending mid-April), and mid-liay to mid-June (ending in July) at temperatures of $17^{\circ}$ to $21^{\circ} \mathrm{C}$.

Size: Not exceeding 80 pounds in eastern Pacific. Larger fishes in offshore shoals.

Katsuwonus pelamis (K.Vagans) - Oceanic skipjack. (Air bladder wanting.)

Range: Point Conception to Galapagos; Oceania; Philippines; Japan; Atlantic. In western Pacific follows the circling Kuroshio current, reaching peak about March in tropical waters to the south and sometime after June around Osh1ma $\left(34^{\circ} 44^{\prime} \mathrm{N} 139^{\circ} 24^{\prime} \mathrm{E}\right)$ and nearby island reefs. Fishing grounds extend $600 \mathrm{miles}$ of Japan coast.

Size: To 36 inches but rarely exceeding 25 .

Neothunnus macropterus - Yellowfin tuna. (Alr bladder narrow.)

Range: Point Conception to Galapagos; Hawaii; IndoPacific; Japan; Atlant1c. Rare north of $35^{\circ} \mathrm{N}$ latitude. 
Usually in water of $60^{\circ}$ to $80^{\circ} \mathrm{F}$. Kiost important tuna of southern Japan, Riukiu and Bonin islands southward to the equator. Sometime in Sea of Japan and north to Hokkaido in summer. Enormous schools in southern Philippines south and east to region north of New Guinea, through Polynesia, and to the Hawailan islands.

Size: Reaches 450 pounds, but not common over 125. Average commercial catch in southwest Pacific under 110 pounds.

Pneumatophorus diego - Pacific mackerel. (Well-developed air bladder.)

Range: Alaska to Cape San Lucas, most abundant on coast of Southern California. Closely related species on coasts of Ecuador, Peru, Chile, and Galapagos.

Size: To 22 inches, $3 \frac{\pi}{z}$ pounds.

Pneumatophorus japonicus - See page 86.

Sarda - Bonitos (Several species)

Range: Paclfic coast from Oregon to Peru; Oceania;

Japan. Near surface of open seas in warm and temperate waters, seldom below 40 meters.

Size: At least 30 inches. 
Scomberomorus - Sierras and Spanish mackerels;

sawara.

Range: Two species on Pacific coast between Santa llonica and Peru. One species restricted to Japan. One species from Chinese and Japanese seas.

Size: California specimens to about 12 pounds.

Thunnus thynnus (T.orientalis) - Bluefin tuna; black tuna; maguro. (Air bladder thin-walled, triangular, very wide and short; straight at anterior end, 1111ing breadth of abdominal cavity but narrowing at midabdomen.)

Range: Worldwide. Lower California to Columbia Rịer; Philippines; Japan; Atlantic; Hediterranean, etc. Fishing season from Santa Cruz Id. to Mexican border, June to september. Found throughout the year off coasts of Japan, in summer northward to the southern end of SakheI in $\left(46^{\circ} \mathrm{N}\right)$. Good hauls always near convergence of warm Kuroshio and colder waters. Also off southeastern coast of Mindanao.

Size: Pacific coast of North America, about 250 pounds maximum. Japanese waters, mid-December to early January, average of catch about 450 pounds; and in midJune, about 387 pounds; maximum records about 825 pounds.

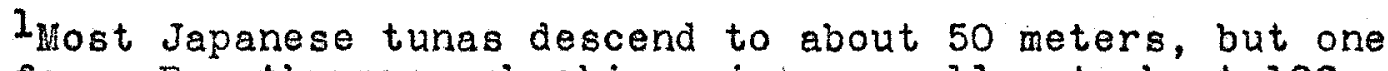
form, Parathunnus mebachi, swims normally at about 100 meters below the surface. 
Sonic importance: Unknown but worthy of investigation because of size, schooling habit, and wide distribution.

\section{SCORPAENIDAE}

Rock fishes; scorplon fishes

That Sebastiscus tsuraara produces a long drawn out guttural sound ${ }^{l}$ as it approaches and swims around "the shaded areas of rocky reefs" is well known to Japanese fishermen of Wisaki, and verified by Uchida (1934). Prodded with a stick, a fish can be made to bring forth the same noise. Whether the air bladder, which is usually present in members of the family, participates sonically is not known.

Scorpaenopsis gibbosus, another Pacific scorpion fish, is included by Vernon $\mathrm{E}$. Brock (letter of March 23 , 1948) in a list of species in which the ability to make noise has been observed. It is described as "a low grinding noise".

The scorpaenoid family is especially abundant in the temperate parts of the Facific, where it forms a large percentage of the fish population, along rocky shores. Several hundred species have been described, of which over 50 frequent the Japanese, and over 30 the Philippine waters.Although mostly of inshore occurrence, some species inhabit deeper

In Japanese the noise is described as "snoring". 
regions, as Sebastolobus alascanus of the Bering sea which ranges southward to California in depths of 109 to 786 fathoms.

Rock fishes are mostly of large size. Common species of the American Pacific coast northmard to Alaska reach lengths of two to three feet.

Sonic importance: Worthy of consideration because of large size and great abundance over large areas in the Pacific.

SILURO IDEA (Order Nematognathi)

Catfishes

Siluroldea, the great group of catfishes, so-called because of their be-whiskered appearance with one or more pairs of long barbels on the mouth, chin, and nostrils, includes more than 2000 species. While the majority are freshwater dwellers, there are a number of species throughout the Indo-Pacific region, Japan and China, that Iive exclusively in the sea or in estuaries. Taxonomists have singled out at least 29 catfish families, but, for the sake of simplicity here, all marine species falling within the scope of this survey will be discussed together (particularly Arildae and Plotosidae).

Wuch has been written of the unique internal anatomy of siluroids and its bearing on sound production. The 
first five vertebrae are rigidly connected to each other

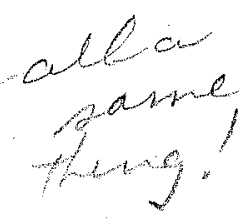

and to the skull, forming, by united spines, a compressed plate of bone with closely set parallel ridges. By alternately flexing and extending the body in the vertical plane, this bony structure scrapes against the succeeding, fertebrae with a resultant harsh scraping noise. I

In siluroids the air bladder is typlcally quite large and connected with the organ of hearing by means of a chain of bones (Weberian apparatus). In some catfish the bladder is subdivided into paired posterior chambers and a transverse anterior chamber. The latter may be more or less completely invested by the projections of elaborately modifled vertebrae. In such species a peculiar "elastic spring mechanism" is developed on either side in connection with the fourth vertebra. One end of a tendinous "spring" fits like a cap over the front of the air bladder and the other end is attached to strong muscles reaching to the back of the skull. By vibrating the spring and muscles, sound is produced and amplified by the chambered air bladder. Some

I Lancaster,E.R., 1909: "A complex vertebra, behind the small first centrum, is made up of three, four, or even five centra, forming a single mass which may be co-ossiflod with the first centrum and the basioccipital. The parapophyses are Iong, especially in front, and those of the fourth, and sometimes also of the fifth vertebra, are immensely enlarged and project outwards to artioulate with the massive post-temporal. The latter has one linb articulating with the basioccipital, and another with the epi- and pterotic. The enlarged parapophyses more or less thoroughly invest the anterior chamber of the air-bladder, sometimes in a complete bony capsule." 
catish have an elaborate fringe of variously sized caeca on the lateral margins of the air bladder.

Bridge (1904) credits the air bladder apparatus with the "hissing of a cat" heard in Malapterurus electricus, and the well known growling produced by such genera as sorubin, Trachelyopterus, Piratinga, Centromochlus, Pimelodus and Platystoma.

Burkenroad (1931) experimented with the channel cat Galeichthys milberti and the gaff-topsail catish Felichthys felis in Louisiana and noted a rapid vibration of a small area of skin just back of the cranial bones on either side of the mid-dorsal Iine, synchronous with the grunt. Dissection showed the alr bladder to be heart-shaped, subdivided internally and firmly fastened to the vertebrae above. Two broad, tendinous bands, loosely attached across the front of the air bladder, are connected on either side to a slender, springy, bone with thin, expended base,along the surface of the body cavity. The contraction of short muscle fibers on the dorsal surface of these bony plates accounts for the external vibrations observed.

Naval Ordnance Laboratory experimenters at Beaufort, N.C. found the rhythmic drumming of E.felis to measure .76 dynes/ $\mathrm{cm}^{2} \sqrt{\text { octave }}$ in the $300-600 \mathrm{cps}$ band. Differing from the "rolls" of the croaker, the catfish arummed in rapid, evenly-spaced beats. The easily recognized sound was heard under natural conditions and messurements were posalble on captive specimens in an experimental enclosure. 
Felichthys is confined to American waters. The two Pacific coast species are common around wharves, coral reefs, and rocky bottoms from the mouth of the Gulf of California to Ecuador, especially about Panama. Average length is under 18 inches.

Galeichthys, also, is an American genus, represented by some half dozen or more species on the Faciflc coast of tropical America.

The marine catfishes of family Plotosidae, of which there are six or more genera reported from the Pacific area, have a moderate air bladder, not encased in bone as in the genera Felichthys and Galeichthys. Uchide (1934) Iists Elotosus anguillaris, the "gigi" or "gonzui", among the sound-producing fish of his country. It is very abundant on the shores of shallow sandy bays throughout southern Japan. Similarly to some freshwater catfishes, the gigi makes a noise like "rolling pebbles" by stridulation of the. pectoral fin base against the body.

The large group of marine Aritdae, with over 30 representatives in western Pacific waters, have the air bladder large, free, and normal. No date are available on the sounds produced by these siluroids, but Dr.A.W.Herre (letter of March 31, 1947), in discussing Philipplne fishes that make underwater noises, states: "Among the most persistent are the salt water members of the genus Arius. As far as I 
am aware, the very numerous fresh water species are not so consplcuous in making noises. The two salt water cat fishes of this group that are most abundant and largest are the following: Arius thalassinus; this reaches a length of 3 to 4 feet. The other is Arlus leiotetocephalus. Nembers of the family flotosidae are very abundant especially in the southern Philippines but I do not know positively that these cat fishes make noises although I suspect they do."

A whining "mew" observed simultaneously with the drumming of certain catfish is the result of stridulation at the base of the pectoral spine. ${ }^{1}$ This moveable bony ray locks in forward position, when slightly rotated in counterclockwise fashion, as a defensive measure. The locking action is silent, but unlocking makes a noticeable creak. In a South American river species, Doras maculatus, sound can be heard above the surface at a distance of 100 feet.

Thus the character of the sound is principally a rhythmic drumming like the beating of a tomtom, (elastic spring mechanism), but with an adoitional dull, low-pltched grunt (vertebral stridulation), and a creading "mew" (pectoral spine stridulation.

Sonic importance: Possible.

1Bridge, 1904: "Stridulation between a basal process from the great spine of the pectoral $f$ in and the wall of a socket in the cleithrum into which the process is received." 


\section{SPARIDAE \\ Porgies; Pargos}

Lagodon rhomboides, the sailor's choice or pinfish, slides the upper and lower incisors on each other to produce a scrapine clash. Burkenroad (1931) describes a peculiar "sneeze-like gasp interpolated occasionally amohg the usual respiratory movements of the fish kept out of water."

Navy experiments with aquarium specimens of L.rhomboldes falled to record sound, but the related sheepshead Archosargus probatocephalus made a loud crunching and grinding durine the process of feeding. No other sounds were noted.

A related species, lionotaxis grandoculis, is widely distributed and fairly numerous in the Facific islands, reaching a length of 22 inches. Several other sparids occur abundantly throughout the Indo-Facific region, Philippines, China and Japan.

Sonic importance: probably none. 
STNGNATH IDAE

Plpefishes and Seahorses

Both sexes of the short-snouted seahorse of Europe Hippocampus brevirostris make a monotonous noise analygous to that of the tambour, especially during the breeding aeason. Dufosse (1874) first desoribes these barely audible sounds, which are accompanied by a long serles of quiverings so slight and rapid as to practically evade the eye.

Gill (1905) reports that the noise results from muscular closing and sudden expansion of the lower jaw, resembling in strength and tone the snapping sound produced by the scarlet prawn, Alpheus ruber. An amusing story is told of an artist who was sketching two seahorses in separate glass jars. Suddenly a sharp little snapping voice called at short and regular intervals from one container, followed by a response from the other. Gill concludes that they were "thus conversing or signalling to each other." Uchida in a 1939 radio broadcast in Japan described a similar episode where two seahorses in separate jars conversed for some time "as if they were exchanging telegraphic code" .

Syngnathus loulsianae was observed by Burkenroad (1931) to make a click quite similar to that of an elaterid beetle by repeated snapping of the head very sharply. upward. 
The family is widespread in the Indo-Pacific region, from Africa eastward through Oceania to Hawail, and northward to the shores of Japan and China, as well as on the troplcal American coast. At least 10 genera and 22 species have been described there. Specimens are small in size. Sonic importance: None.

\section{TERAPON IDAE}

Theraponids

This family includes several genera of small or moderate sized fishes from the Indian and west Pacific Oceans, including the east coast of Africa, Madagascar, Red Sea, India, East Indies, Australia, Philippines, China, Japan, Formosa and Samoa. Most species may be found in brackish water as well as in the sea, and some enter freshwater. The air bladder is characteristic, being divided by constriction into two compartments.

Bridge (1904) includes the genus Therapon in a m1scellaneous list of fishes that are believed to produce sound by means of the air bladder.

Uchida (1934) Iists Therapon oxyrhynchus and T.servus among the sonic fishes of Japan. No description is given of the sound produced but it is "familiar to many fishermen ... and ... produced in the water ... can be heard above the Burface." 
About 39 species of four genera are reported from the Indo-Australian region, and 11 from the Philippines. Only three species, Pelates quadrilineatus, T.oxyrhynchus, and $I$.jarbua (T.servus), are known on the coast of Japan. The largest of the Japanese species is less than a foot in length. I.oxyrhynchus may be fairly abundant at times in southern Japan for it is reportedly used there as a cheap food fish.

Sonic importance: Questionable.

\section{TETRAODONTIDAE}

Puffers

SIuggish inhabitants of all warm seas, the puffer family is represented by numerous species from the East Indies to China and Japan, Cceania, and the Pacific coast of tropical America.

A stridulatory sound, high pitched and nasal, is produced during and following inflation by grating of the incisor teeth, well known for such common species as Spheroides splengler1. Uchida (1934) lists the following species as sound-producers in Japan: S.chrysops, S.niphobles, S.pardalis, S.porphyreus, S.rubripes, and S.xanthopterus. 
Pappe (1853) records the sound of Tetraodon honckenii as a growl, similar to that of the trunkfish Ostracion upon being taken from the water. For the most part puffers are small fishes reaching not more than a foot in length.

Sonic importance: Probably none.

TRIACANTIIDAE

Three-spined filefish

Stridulation of the anterior dorsal fin, as well as the pelvic $f^{1}$, is responsible for the scraping sounds reported for species of Triacanthus. I.brevirostris ${ }^{2}$ and I. biaculeatus, whose range is the East Indies, China and Japan, are capable of sound production by means of the air bladder and associated muscles (Bridge 1904). Uchida (1934) includes $\underline{T}$ brevirostris amone the sonic fishes of Japan but states that he has not himself witnessed the reported sound production.

The family occurs throughout the western Pacific area, in Australia, East Indies, Philippines, China and Japan.

Sonic importance: Frobably none.

Istridulation between the spinous ray of the pelvic and the basipterygium.

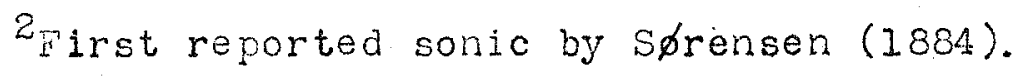




\section{TRIGL IDAE}

Gurnards; Sea robins

One of the groups of noisiest reputation is the gurnard family, including the sea robins of American waters and many of the typical "mail-cheeked fishes" of the Far East. Early European papers comment on the sound-making ability of local triglids, and vernacular names of "piper" for Irigla lyra and "crooner" for I.gurnardus were coined. Murray (1831) remarks that "the gurnard will continue to grunt like a hog for considerable time when caught and lies at the bottom of the boat." Again, to quote Cuvier (1834): "Many species utter, when taken, sounds, which cause them to: be named grumblers." In a letter from J.T.Nichols (1947) the "grr of the common Atlantic sea robin Prionotus carolinus" is compared to "the grunting of a startled bittern on taking wing out of a marsh," and Navy investigators describe its sound as "a modulated, rhythmic squawk, squeal or cackle, resembling noises ordinarily associated with a barnyard." (N.O.L.R.NO.880).

Sorensen (1894) discusses the function of the air bladder in T.lyra and T.hirundo in the production of their characteristic sounds. Bridge (1904) describes further the division of the air bladder into "two intercommunicating compartments by a transversely-disposed and centrally-perforated diaphragm." As in the Batracholdidae, the grunting noises are produced by special muscles lying in the walls 
of the air bladder itself, "Intrinsic" muscles instead of the "extrinsic" muscles of sciaenidae.

Norman (1931) experimented with living gurnards and succeeded in obtaining a perfectly normal sound by artificially stimulating either the muscle or the nerve supplying the air bladder, even after the bladder was removed from the fish. Puncturing of the bladder, however, silenced its sound. Insertion of a rubber balloon led to sound again when the muscle was stimulated by electricity. The apparatus described by these various exper1menters is adapted to sounds repeated at fairly long intervals. The actual noise has been described as crooning, snoring, piping, squealing, cackling and grunting. Tower (1908) likens the sound to that made "by drawing the forefinger and thumb towards each other over the surface of an inflated rubber balloon."

The croaking of a 200 millimeter Chelidonichthys kumu in the well of a fishing boat on August 11, 1926, is noted by Uchida (1934). "In this case, too, the vibrations of the air-bladder were felt when a finger was pressed against the fish's side." An identical sound, but of lower pitch, is recorded for specimens of Lepidotrigla gunther1 of 70 to 90 millimeters.

Naval Ordnance Laboratory investigators learned to easily differentiate the sound of sea robins (Prionotus 
carolinus) in the vicinity of Beaufort, N.C., although; due to the medley of other sound-makers, it was impossible to determine sound levels in fleld measurements. Spectra of captive specimens measured about 21 dynes/cm ${ }^{2}$ in the 150 to 300-cps octave.

The genus Prionotus is quite widely distributed on the Pacific coast of America, as well as the Atlantic. One species, closely related to the sea robin used in the above experiments, is reported from Peru to the Gulf of California, at depths of 7 to $51 \frac{2}{2}$ fathoms. Although never approaching close to shore, collections indicate that the juveniles at least come to or near the surface at night.I Yamada (194I) included Chelidonichthys kumu and Lepidotrigla microptera in a list of the sonic fishes of Japan. Avallable literature does not mention sound-making further for the gurnards of the northwestern Facific, but It is probable that they will be found among the worst offenders there, just as their near relatives are in Atlantic waters.

Of the more than 40 species known, 29 are recorded from the Pacific region. Some frequent rocky shores while others live in rather deep water. L.microptera, in general the most abundant Japanese triglid, ranges well northward on the shores of Japan and Korea, and out into water of

1 Purse seine records, 3 miles of Cañete, Peru (Hildebrand, 1946). 
65 fathoms or more. I.guntheri, which frequents the coast northward to Tokyo, has been taken in depths up to 108 fathoms, and L.abyssalis, as the name implies, is confined to rather deep water in the same localfty. AIBATROSS specimens of the latter were dredged at 50 to 107 fathoms. Normally the gurnard crawls along the bottom, using three curiously adapted free pectoral rays, which resemble curved fingers, as legs for progression and for overturning stones in search of food.

The genus Chelidonichthys has a wide geographical range from New Zealand to Chosi (Ibaragi Frefecture), Japan and China. Numerous species abound in India, Africa, and Europe but only the following species has been reported from Japan. ${ }^{1}$

Chelidonichthys kumu, the red or kumu gurnard, is abundant in Australia and New Zealand, where it is a common food fish, occurring elsewhere along the south African coast, Malay Archipelago, China, and Japan northward to Hakodate, Hokkaido. Young examples are reportedly common on the bottom around rocky headlands (e.g. the lower parts of Port Jackson, Australia).

Range: New Zealand to northern Japan. Size: To 20 inches length.

$I_{\text {Another species, }}$. 1 schyurus was described by Jordan and Thompson from sagami Bay, but has not been recorded since. 
Lepidogrigla is nearly endemic to Japanese waters, extending from Hokkaido to Formosa. Only a few species are found in the Indian Ocean. Because of the many species and their abundance along the coasts of Japan both in shallow and in deeper waters, the possibility of sonic disturbance must be considered for this genus.

Lepidotrigla microptera is reportedly the most abundant species in Japan, except around Nagasaki where L.alata is most prevalent. It ranges well northward along the shore, running out into water at least 65 fathoms deep (ALBATROSS record off Ose Point, Suruga Bay).

Range: Japan, north to Hokadate; China

Depth: To 65 fathoms

Size: About 8 inches.

Although no gurnards have been taken in mid-Pacific about the oceanic islands east of New Guinea, many species frequent the tropical coastal waters between Ecuador and the Gulf of California, and in the far western Pacific between New Zealand and northern Japan.

Sonic importance: Possibly considerable. 


\section{ZEIDAE}

John Dories

Four species, representing four genera, of short, singularly deep and compressed Zeldae occur in Japanese waters between Tokyo and Nagasaki, and two other species in the Philippines. Several related genera inhabit the warmer parts of the Atlantic, some at considerable depths. 1 For one of these, Zeus faber, Bridge (1904) calied attention to sound production through the action of special muscles lyine within the walls of the air bladder, "analygous to that of eurnards."

Sonic importance: Negligible.

1Parazen pacificus was described off Kochi, Japan at a depth of 80 fathoms. 
$S U M A R Y$ O $F$ IN $S O N I C S P E C I E S A N D$ S U G E E S I ONS F.OR FURTHER INVESTIGATION

Chart I, which follows, summarizes our knowledge of sonic fishes in the Pacific. Forty-one families of reported noise-makers are ilsted, together with the character and origin of sound produced by each group, and its general geographical distribution in the Pacific.

Chart II summarizes the estimated sonic importance of the various families, taking into consideration the ir abundance, distribution, size of individuals, or igin and type of sound. It is conceivable that in some cases a single specimen could seriously interfere with underwater sound reception, but usually only those species that gather in great numbers at moderate to shallow depths will be expected to be troublesome. Iikewise those forms with specially developed sonic organs are of greater importance than those in which sound production is only incidental to eating, or of any external stridulatory origin. 


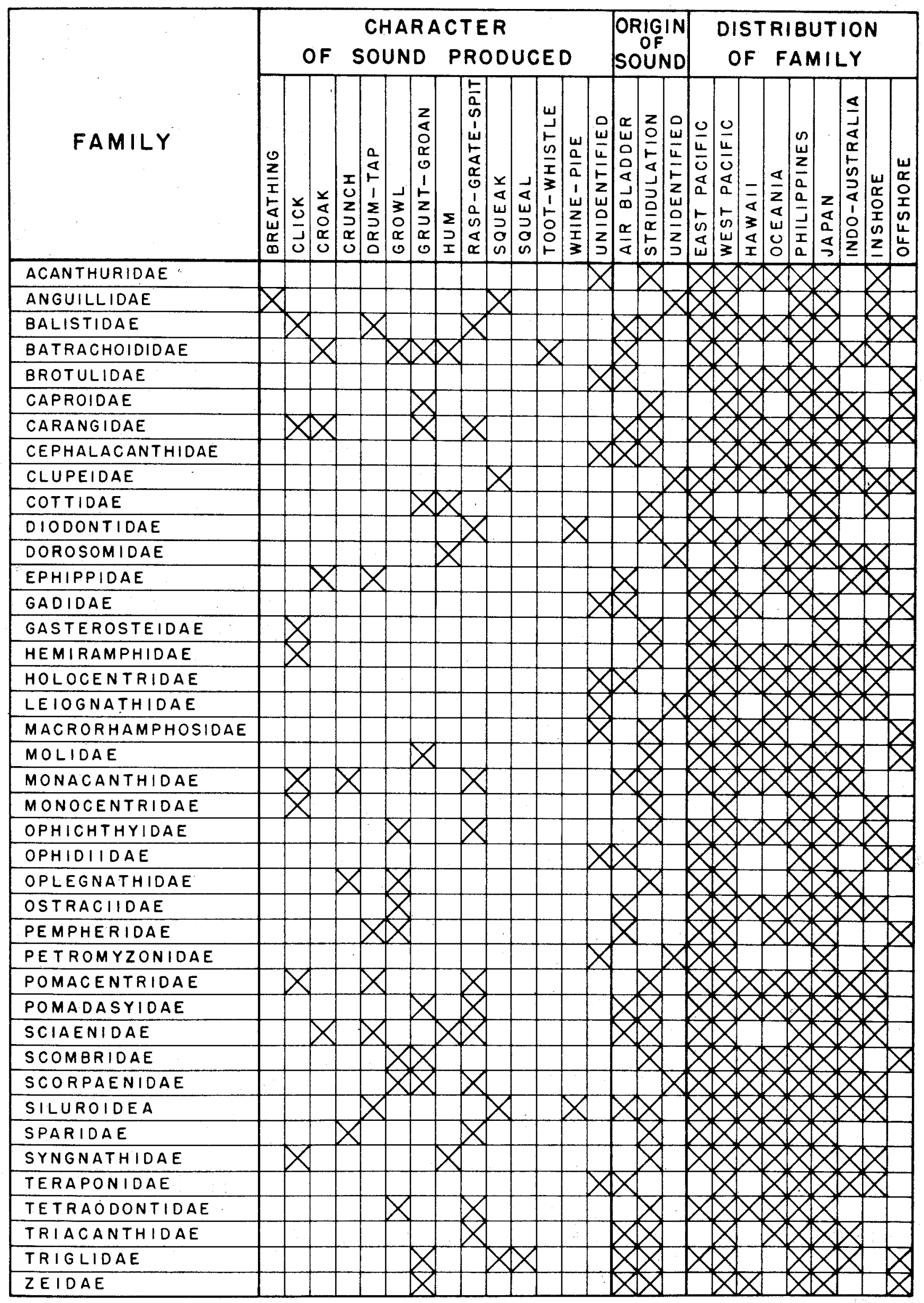

TABLE I - Origin and type of sounds produced, and geographical distribution of sonic families. 


\begin{tabular}{|c|c|c|c|c|c|}
\hline \multirow[t]{2}{*}{ FAM ILY } & \multicolumn{4}{|c|}{$\begin{array}{l}\text { ESTIMATED SONIC IMPORTANCE } \\
\text { UNDER VARIOUS CONDITIONS }\end{array}$} & \multirow{2}{*}{$\begin{array}{c}\text { WARRANT } \\
\text { FURTHER } \\
\text { STUDY }\end{array}$} \\
\hline & NONE & SLIGHT & MODERATE & CONSIDERABLE & \\
\hline \multicolumn{6}{|l|}{ ACANTHURIDAE } \\
\hline \multicolumn{6}{|l|}{ ANGUILLIDAE } \\
\hline \multicolumn{6}{|l|}{ BALISTIDAE } \\
\hline \multicolumn{6}{|l|}{ BATRACHOIDIDAE } \\
\hline \multicolumn{6}{|l|}{ BROTULIDAE } \\
\hline \multicolumn{6}{|l|}{ CAPROIDAE } \\
\hline \multicolumn{6}{|l|}{ CARANGIDAE } \\
\hline \multicolumn{6}{|l|}{ CEPHALACANTHIDAE } \\
\hline \multicolumn{6}{|l|}{ CLUPEIDAE } \\
\hline \multicolumn{6}{|l|}{ COTTIDAE } \\
\hline \multicolumn{6}{|l|}{ DIODONTIDAE } \\
\hline \multicolumn{6}{|l|}{ DOROSOMIDAE } \\
\hline \multicolumn{6}{|l|}{ EPHIPPIDAE } \\
\hline \multicolumn{6}{|l|}{ GADIDAE } \\
\hline \multicolumn{6}{|l|}{ GASTEROSTEIDAE } \\
\hline \multicolumn{6}{|l|}{ HEMIRAMPHIDAE } \\
\hline \multicolumn{6}{|l|}{ HOLOCENTRIDAE } \\
\hline \multicolumn{6}{|l|}{ LEIOGNATHIDAE } \\
\hline \multicolumn{6}{|l|}{ MACRORHAMPHOSIDAE } \\
\hline \multicolumn{6}{|l|}{ MOLIDAE } \\
\hline \multicolumn{6}{|l|}{ MONACANTHIDAE } \\
\hline \multicolumn{6}{|l|}{ MONOCENTRIDAE } \\
\hline OPHICHTHYIDAE & 71 & & & & \\
\hline OPHIDIIDAE & Dtts & & & & \\
\hline OPLEGNATHIDAE & Dt & & & & \\
\hline OSTRACIIDAE & Et & & & & $\theta$ \\
\hline PEMPHERIDAE & 711 & 72717 & & & \\
\hline PETROMYZONIDAE & 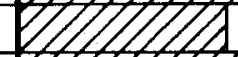 & & & & \\
\hline POMACENTRIDAE & 00110711 & & 770111 & & + \\
\hline POMADASYIDAE & EDOtOS & & 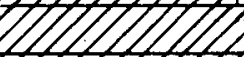 & 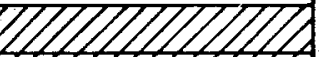 & + \\
\hline SCIAENIDAE & & & & 2111111 & + \\
\hline SCOMBRIDAE & & & & & + \\
\hline SCORPAENIDAE & DEt & & 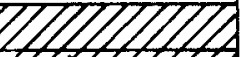 & & + \\
\hline SILUROIDEA & D & & & & + \\
\hline SPARIDAE & Dt & & & 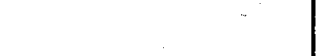 & \\
\hline SYNGNATHIDAE & DI & & & & \\
\hline TERAPONIDAE & Dt & & & & \\
\hline TETRAODONTIDAE & 719 & & & & \\
\hline TRIACANTHIDAE & 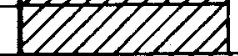 & & & & \\
\hline TRIGLIDAE & 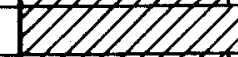 & 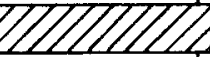 & 77 & 77 & + \\
\hline ZEIDAE & 0700111 & & & & \\
\hline
\end{tabular}

TABLE II - Estimated sonic importance of various fomilies. 
BATRACHOIDIDAE ${ }^{2}$ : The toadfishes have already proved capable of considerable importance to underwater equipment. Naval Ordnance Laboratory conclusions (N.O.L.R.No.880), following preliminary experiments on Atlantic toadfish were: "The Batrachoididae might have considerable effect on underwater acoustic devices because of the character and volume of their noise and their proclivity for living under such obstructions as mine cases. Even a single toadfish specimen could fire an acoustic mine having proper response characteristics." Sound pressures reached 250 dynes $/ \mathrm{cm}^{2}$ in the 150 to 300-cps octave, when close to the hydrophone. The noise is described as an "intermittent, low-pitched musical blast of about 1/2-second duratioh, somewhat similar to a boat whistle, and is concentrated at the low-frequency end of the spectrum", with a second noise resembling "a raucous grunt of about the same intensity, duration, and pitch, but of different quality."

Toadfishes are numerous in the warm waters of the Indo-Australian region north to the Philippines, and on the Pacific coast of the Americas from Peru to California.They are usually confined to the bottom in fairly shallow water, but some species have been dredged at depths up to 40 fathoms.

Sucgestions: Information on the California singing ish or midshipman, porichthys notatus, could be quite easily

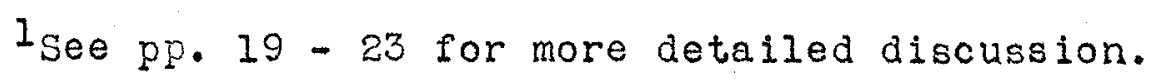


gathered. This species is abundant at many places along the coast between Lower California and Puget Sound, living near shore to the north but in deeper water (up to 40 fathoms) southward. It reaches a length of 15 inches. The toadish Coryzichthys diemensis, which is widespread through the East Indies, is reported from the PhilIppines, especially from Palawan and Panay. Investigation of this species is recommended.

CLUPEIDAE: ${ }^{1}$ The importance of herring to underwater acoustic equipment is probably negligible, but is worth investigating. If great concentrations of herring made noise at the surface similar to croakers, that fact would have been noted repeatedly. However isolated specimens have been reported capable of sound production, and should this prove a common occurrence underwater, it could prove significant. Herring are gregarious fishes swimming usually in immense schools, and because of their great numbers constitute the most important commercial family in the western Pacific. Species are widely distributed from the Indo-Australian Archipelago to China, Korea, Japan, Philippines, Hawail, and the American coast from Peru to Alaska.

ISee pp.32-33 for more detailed description. 
Suggestions: Experimentation would be comparatively simple throughout their range, and either positive or negative results valuable. Both the Japanese sardine (Sardina melanosticta) and the California sardine (Sardinops caerulea) whose migrations are well known (see p.33) are suggested for study particularly during the breeding season. Attempts for sonic information on related larger forms, as the milkfish (Chanos chanos) and tarpon (Kegalops cyprinoldes) are recommended in the Philippines, where both occur in abundance.

COTTIDAE: ${ }^{1}$ Although so far there is no evidence of their interference with underwater acoustic gear, sculpins are well known noise-makers in the eastern Pacific. The sound is described as a low drumming or grunting, produced by rubbing the gill covers against the side of the body. There is no air bladder. It is improbable that the intensity of sound will be found dangerously great, but the large numbers of sculpin in the North Pacific make defintie information desirable.

There are some 121 different sculpins described from northern Japanese waters and the Pacific coast of North America. A single species is recorded from the Philippines. Most common habitats are rock pools and inshore waters, although

$1_{\text {See }}$ pp. 34-36 for more detailed discussion. 
certain marine forms descend to considerable depths. Some sculpins reach 18 inches or more, but mostly they are about a foot in length.

Suggestions: Elther the buffalo sculpin, Aspicottus bison, or the smooth cabezon, Leptocottus armatus, could be quite easily studied. Both species occur along shore from San Francisco to Alaska, very abundantly in the Puget Sound area. Any investigations carried on northward might well include some of the 12 species of Myoxocephalus which are extremely common on the coasts of Alaska, Aleutians, Kamchatka, and northern Japan.

EPH IPP IDAE: ${ }^{1}$ The spadefish or angelfish reportedly makes a "faint drumming" and a "grating croak", which description does not indicate appreciable influence on underwater acoustic gear. However, inamuch as it is known to possess a well developed, specialized mechanism for sound production, and since individuals reach two to three feet in length, the spadefish is a potential sound-maker of importance.

One species, Chaetodipterus zonatus, occurs from San Diego to northern Peru, and is very common about Panama.

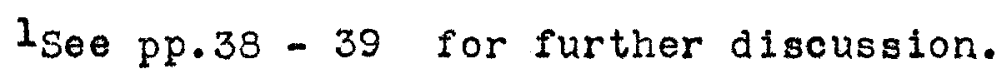


Alled forms, Ephippus argus and E.orbis, occur throughout the Indo-Australian Archipelago to China, Formosa, and the Philippines.

Suggestions: Sound measurements for both of the above genera are desirable. Chaetodipterus is a common food fish in Fanama waters and should not be difficult to locate. Ephippus is especially common in the Philippines where it can be trapped in shallow bays or in bodies of brackish or fresh water not far from the sea. In Manila Bay this spadefish is caught for market by hook-and-line fishermen.

GADIDAE: ${ }^{1}$ There is little probability that the codfish family will be found of importance to underwater acoustic gear, but their very large ize and tremendous numbers in northern regions makes it advisable that any possibility of sound production be investigated. The only evidence to date is the observation of Bridge (1904) that certain gadoids (cod, Gadus, and haddock, Melano- grammus) are sonic through the agency of the air bladder and associated muscles. The alr bladder of the common Atlantic cod is peculfarly formed, with a pair of sac-like

$1_{\text {See }}$ pp.40-41 for further discussion. 
prolongations extending forward to the head, often curiously colled. It is very desirable to learn whether other gadoids, especially the larger ones, use a specialized air bladder mechanism for sound production.

Members of the cod family occur in Hawai, along the west coast of America from the deep waters of $f$ Panama to Alaska, and most abundantly from the Bering and Okhotsk sea areas to Japan. A single species has been taken in the Philippines.

Suggestions: Since gadold concentrations are well known to fishermen, study of the very abundant Alaska codfish (G.macrocephalus) could be arranged on any of its fishing banks. The species occurs in great numbers off both shores of the Bering Sea in depths of 15 to 130 fathoms, ranging westward to Hokkaido and eastward to the offshore banks of Oregon.

Investigations in the same region should include the Alaska pollock, Theragra chalcogramma, which is excessively common in the Bering Sea. Specimens reach three feet or more in length. Information on any other available gadolds is advisable. 
HOL IDAE: ${ }^{I}$ That ocean sunfish "grunt and groan" by grating their teeth, in the manner of pigs and other ruminants, is well known. Because individuals reach tremendous size (4400 pounds in the Indo-Pacific), stridulatory sound may assume considerable magnitude. The fact that these glants may be met with of $f$ any warm temperate or tropical coast makes information on the ir sound production advisable. Various species are frequent of the coasts of $\mathrm{Cal}-$ ifornia, Hawai, and Australia to Japan, although they are reported rare or absent across the great breadth of the Pacific.

Suggestions: The large size and pelagic habits of the ocean sunfish make capture and imprisonment for experimentation difficult, but if a means of recording can be devised, it should provide valuable results.

POMACENTRIDAE? All members of this large family have the lower pharyngeal teeth fused into a solld plate which gnashes noisily against the upper teeth, and an air bladder which may amplify the stridulatory sounds. Naval Ordnance Laboratory investigators showed that some species

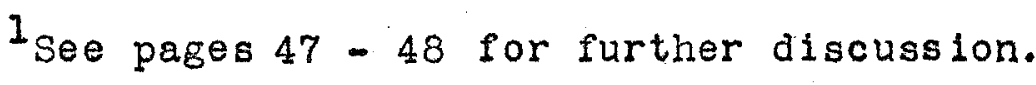

2 See pages $59-63$ for further discussion.
} 
are capable of considerable sound. Loud clicking and ressping was heard during feeding experiments, and a spontaneous drumming or tapping at other times, especially by individuals in pursuit of others. In a tank of 35 large (one foot long) garibaldi, Hypsypops rublcundus, the recorded pitch was low with most of the energy concentrated in the 75 to 100-cps octave and pressure reachlng 22 dynes/ $\mathrm{cm}^{2}$. For the much smaller (three inch) demoiselles, Dascyllus trimaculatus, pressure in the same band barely reached 6 dynes $/ \mathrm{cm}^{2}$. Although the sound amplitude of an individual specimen is not great, the noise produced by great concentrations of these active and abundant little fishes could be considerable.

Over 200 species are recorded from the warmer parts of the Pacific region, distributed almost everywhere in association with reefs or rocky shores.

Suggestions: Garibaldi, which reaches 14 inches in length, is common in clear waters from Point Conception southward along the Lower California coast. Sound recordings are suggested here, and in the Philippines or Hawailan Islands where pomacentrids of many species are extremely abundant. 
FOMADASYIDAE: ${ }^{1}$ The guttural noise produced by most members of this family by means of pharyngeal teeth with the aid of a complex air bladder accounts for their popular name of grunt or grunter. Although the sound produced by a single specimen is not loud enough to bother underwater gear, the fact that grunts gather in enormous schools in the breeding season, and are of great abundance at all times alone such rocky shores as those of the southern Philippine islands, suggests that a grunter chorus of large proportions is possible.

Disc recordings (N.O.L.R.No.880) of the Atlant1c hogfish (which is little differentiated from Facific relations) indicate that the sound is a spontaneous harsh rasping, 4 or 5 rasps in rapid succession, and reaching about 2.3 dynes $/ \mathrm{cm}^{2}$ in the 200 to $400-\mathrm{cps}$ octave. Its intensity, therefore, exceeds that of the croaker which is known to produce en masse sufficient sound to be of serious consideration.

Nembers of the pomadasid family are numerous in warm water along the Pacific coast of the Americas, throughout Oceania, and from South African and Indo-Australian shores to Japan. Some of the numerous and widespread species reach three feet in length.

$I_{\text {See pages }} 63-66$ for further discussion. 
Suggestions: Investigation of any of the ten or more grunts that are fished commercially in the Philippines could be made. Attention should be given particularly to the genera Plectorhynchus and Farapristipoma in Japanese waters between Tokyo and Nagasaki.

SCIAENIDAE: ${ }^{1}$ The croaker or drumfish family, of long established noisy reputation, is now known to produce. enough sonic disturbance to effect even the use of certain types of acoustic mines. Preliminary sound measurements indicated croaker noise to reach 85 dynes $/ \mathrm{cm}^{2} \sqrt{\text { octave in }}$ the 200 to $400-\mathrm{cps}$ band, and $120 / \mathrm{cm}^{2} \sqrt{0 c t a v e}$ in the 400 to 800-cps band. At Beaufort, N.C. "noises were audible under water at 25 feet from the source ... The superposition of many simultaneous individual bursts from these can give rise to a noise level comparable in magnitude to that of a ship." (N.O.L.R.No.880).

All measurements to date have been confined to American species. However closely related croakers with similarly highly developed sound-making organs occur along the sandy shores of most tropical and temperate seas and must be reckoned with everywhere within their range. In addition to this rather general distribution, their habits are

$I_{\text {See pages }} 66-84$ for further discussion. 
a source of annoyance to underwater acoustic gear. Many species are wont to congregate in huge schools in such protected areas as harbor entrances, and some attain large size. Observations in American, Japanese and Korean Iocations have shown the height of noise-making to come at dawn and dusk, at those times when listening devices must be particularly alert.

Sciaenids occur in abundance about southern California and Panama, the Indo-Australian Archipelago, Fhilippines, Japan, China and Korea, but none seem to have penetrated to the oceanic islands east of New Guinea. They are inshore flshes, for the most part avoiding deep water or rocky bottom. A few venture into relatively cool water, but none tolerate really cold water.

Suggestions: Since croaker noise reaches its height during breeding, that season is suggested in each case for the collection of data. Sound measurements for the following species would be of considerable value:

on the coast of southern California:

1. White bass (Cynoscion nobilis) in May and June.

2. Spotfin croaker (Roncador stearnsi) during summer months. 
In Yellow and China Sea area:

1. Kandari (Coll1chthys fragilis, C.niveatus, . lucidus) from mid-May to late June near Moppo, Korea.

2. Guch1 (Nibea albiflora, N.argentata, N.goma, $\underline{N} \cdot \underline{\text { nibe, }} \mathbf{N} \cdot$ sina), at the end of April and first of May around Moppo.

3. Püse (Fseudosclaena amblyceps, P.crocea, P.manchuria, E.indovittata) from early June to late July near Moppo; from end of March farther south alone the China coast.

In Philippine Islands:

Sound measurements of any of the eight species which are generally distributed through the region are desirable. No data are available at the present time.

SCOMBRIDAE: I No information is available on the mackerel's contribution to the undersea chorus but there is reason to believe that at times it may be considerable. Common species that lack an air bladder are capable of bringing forth harsh grunts by grinding their pharyngeal teeth. Add to this ability a well developed air bladder in a mackerel that swarms in Facific waters (as the common

$I_{\text {See pages }} 85-91$ for further discussion. 
saba, Pneumatophorus japonicus), and the possibility of sound production cannot be overlooked. Apparently the Japanese were suspicious of the above species, for it was singled out for sonic study (Fish 1944).

Sometimes two million mackerel are landed at one Korean port in a single day. Gigantic schools of oceanic bonito (Katsuwonus pelamis) occur in Japanese waters, in the Philippines and Hawail. One concentration described off the north coast of Oahu covered 900 square miles(Herre 1940). The family is of worldwide distribution in temperate and tropical regions, straying occasionally into arctic and subarctic waters. At least 40 species are reported from the area under consideration, some of them of tremendous size (e.E. the bluefin tuna, Thunnus thynnus).

\section{Suggestions: Investigation of the common Pacific} mackerel (D.diego) alone the coast of southern California is proposed, and of the saba (E.japonicus) and oceanic bonito (K.pelamis) in the waters of Jopan. The oceanic bonito and the yaito (Euthynnus yaito) could be studied in the Philippines as well. Collection of data would be facilitated by the fact that all of the above species are fished commercially and details of migrations well known throughout their range. Information on the bluefin tuna or any other large scombrid encountered would be of great value. 
SCORPAENIDAE: ${ }^{1}$ Although the sounds of individual specimens thus far recorded are not loud enough to seem important, the fact that this family is tremendously abundant throughout the temperate parts of the Pacific Ocean, suggests that noise en masse could be considerable. On many rocky coasts, scorpion fishes form a large percentage of the population. Over 30 species have been recorded from the Philippines, over 50 from Japan, and several hundred throughout the world. Some occur in deep water, as Sebastolobus alascanus, of the Bering sea and southward to CalIfornia in depths of 109 to 786 fathoms.

No measurements of sound have been made, but observers in Japan and the fhilippines report a long-drawn-out guttural or grinding noise produced by local species.

Suggestions: Any of the species humerous over the rocky shores on either side of the Facific would be useful for sound measurement.

SILUROIDEA: ${ }^{2}$ As in the case of the croaker family, the catfish has a specially developed apparatus for soundmaking. In some cases it consists of hichly modified vertebrae, chambered air bladder, tendons and muscles forming an elaborate "elastic-spring mechanism".

1 See pp.91-92 for further discussion.

$Z_{\text {See pp.92-97 for further discussion. }}$ 
W1th the exception of one Atlantic catfishl no actual sound measurements have been attempted, al though their noisy habits have been known for years. The sound is a rhythmic drumming suggestive of a tomtom (elastic spring), with an additional dull, low-pitched grunt (scraping of vertebrae), and a creaking "mew" (scraping of pectoral spine).

Numerous marine catfishes frequent the sandy shores of the tropical west facific, particularly at river mouths, bays and lagoons. Information is not yet avallable, but the known noisiness of related forms elsewhere suggests sonic possibilities for them. In a South American river species the drumning is audible for a distance of 100 feet.

Suggestions: Sound measurements for the two Felichthys species that are common around wharves, coral reefs, and rocky bottoms from Echador to the Gulf of California, particularly about Fanama, and for the various Galeichthys encountered in the same region, should be attempted.

since we have no records of sound-making among the Arildae, any data on the various sea catfishes of the Philippines would be valuable. The most abundant and largest are the tabomomo (Arius thalassinus) and the bunguan (A.leiotetocephalus). Both are quite generally distributed, but the tabomomo is caught in greatest quantity in llanila Bay, and the bunguan in San Miguel Bay.

${ }^{l_{\text {See }}}$ p.94 for N.O.I. experiments. 
TRIGL DAE: ${ }^{1}$ The gurnard family, which includes the sea robins of American waters and many of the typical "mailcheeked fishes" of the Far East, has the reputation for being one of the noisiest groups in the sea. As with the toadfishes, their grunts are produced by means of special muscles lying in the walls of the air bladder itself.

Naval Ordnance Laboratory sound measurements of captive Atlantic sea robins reached 21 dynes $/ \mathrm{cm}^{2}$ in the 150 to 300-cps octave. It is concluded that the gurnards, as well as the croakers, because of the tendency to congregate in large schools, can "give rise to a noise level comparable in magnitude to that of a ship". (N.O.L.R.No.880)

Two gurnards were included in a list of the sonic fishes of Japan (Yamada 1941). No further mention has been discovered in available literature, but it is probable that this family will be found among the worst offenders in the western Pacific.

Although gurnards have not been taken in mid-Pacific or about the oceanic islands east of New Guinea, they are frequent in the tropical coastal waters between Ecuador and the Gulf of California, and in the far western Pacific between New Zealand and Hokkaido.

Suggestions: So suspicious are the gurnards, that sonic data on any member of the family will be valuable,

$1_{\text {See }}$ pages 102-106 for further discussion. 


$$
\begin{aligned}
& \text { especially on the sea robin of Panama Bay (Frionotus } \\
& \text { quiescens), the hobo (Chelidonichthys kumu) and the kana- } \\
& \text { gasira (Iepidotrigla microptera) in Japanese waters south } \\
& \text { of Tokyo, and their Philippine relative L.eydouxii. }
\end{aligned}
$$


SPECIES SUGGESTED FOR FURTHER INVESTIGATION

ON THE NORTHERN PACIFIC COAST OF NORTH ANERICA

\begin{tabular}{|c|c|c|}
\hline $\begin{array}{l}\text { COMMON } \\
\text { NAME }\end{array}$ & $\begin{array}{l}\text { SC IENT IF IC } \\
\text { NAME }\end{array}$ & $\begin{array}{l}\text { CENTERS OF } \\
\text { ABUNDANCE }\end{array}$ \\
\hline Midshipman & Forichthys notatus & $\begin{array}{l}\text { Lower California north to } \\
\text { Fuget Sd. Spring breeder. }\end{array}$ \\
\hline Pilchard & Sardinops caerulea & $\begin{array}{l}\text { So.Oregon to Queen Char- } \\
\text { lotte Is. Jun.-Oct. }\end{array}$ \\
\hline $\begin{array}{l}\text { Buffalo } \\
\text { sculpin }\end{array}$ & Aspicottus bison & $\begin{array}{l}\text { Puget Sd. (San Francisco to } \\
\text { Alaska). Spring breeder. }\end{array}$ \\
\hline $\begin{array}{l}\text { Smooth } \\
\text { capezon }\end{array}$ & Leptocottus armatus & $\begin{array}{l}\text { Fuget Sd. (San Diego to Ko- } \\
\text { diak). Spring to early sum- } \\
\text { mer breeder. }\end{array}$ \\
\hline Sculpins & $\begin{array}{l}\text { Cottidae (any of } 12 \\
\text { sp.,especialiy } \\
\text { Myoxocephalus) }\end{array}$ & $\begin{array}{l}\text { Alaska, Aleutians (to Kam- } \\
\text { chatka and No.Japan. }\end{array}$ \\
\hline Alaska cod & Gadus macrocephalus & $\begin{array}{l}\text { Bering Sea, (offshore Ore- } \\
\text { gon banks to Hokkaido). } \\
15 \text { to } 130 \mathrm{f} \text {. }\end{array}$ \\
\hline $\begin{array}{l}\text { Alaska } \\
\text { pollock }\end{array}$ & $\frac{\text { Theragra }}{\text { chalcogramma }}$ & $\begin{array}{l}\text { Bering Sea (Sitka to Toy- } \\
\text { ama B.) Near surface. } \\
\text { Spring breeder. }\end{array}$ \\
\hline $\begin{array}{l}\text { Puget Bay } \\
\text { pollock }\end{array}$ & Theragra fucensis & $\begin{array}{l}\text { Puget Sd. (Vancouver to } \\
\text { Wonterey). Spring breeder. }\end{array}$ \\
\hline $\begin{array}{l}\text { Ocean } \\
\text { sunfish }\end{array}$ & Mola mola & $\begin{array}{l}\text { Gray's Hor.Channel, Wash. } \\
\text { Summer. }\end{array}$ \\
\hline Albacore & Germo alalunga & Offshore in summer \\
\hline Rockfish. & $\begin{array}{l}\text { Scorpaenidae } \\
\text { (many sp.) }\end{array}$ & $\begin{array}{l}\text { Along rocky shores, } \\
\text { widely distributed. }\end{array}$ \\
\hline
\end{tabular}

Table $1 / 3$ 
SPECIES SUGGESTED FOR FURTHER INVESTIGATION ON

THE SOUTHERN PACIFIC COAST OF NORTH AND CENTRAI AMERICA

\begin{tabular}{|c|c|c|}
\hline $\begin{array}{l}\text { COMMMON } \\
\text { NAME }\end{array}$ & $\begin{array}{c}\text { SC IENTIF IC } \\
\text { NAME } \\
\end{array}$ & $\begin{array}{l}\text { CENTERS OF } \\
\text { ABUNDANCE } \\
\end{array}$ \\
\hline Midshipman & Porichthys notatus & Lower California north \\
\hline Filchard & Sardinops caerulea & $\begin{array}{l}\text { Pt.Conception to San } \\
\text { Diego, Har.-Jun. } 1 \text {; Oct. } \\
\text { - War. 2; Nonterey-San } \\
\text { Francisco, Aug.-Mar. }\end{array}$ \\
\hline Spadefish & Chaetodipterus zonatus & Fanama (San Diego-Feru) \\
\hline $\begin{array}{l}\text { Ocean } \\
\text { sunfish }\end{array}$ & Mola mola & $\begin{array}{l}\text { San Francisco-Mazatian. } \\
\text { Surface, off coast }\end{array}$ \\
\hline Garibaldi & Hypsypops rubicundus & Lower Cal. coast \\
\hline $\begin{array}{l}\text { Pacific } \\
\text { mackerel }\end{array}$ & Pneumatophorus diego & $\begin{array}{l}\text { Southern California } \\
\text { (Alaska to C.San Lucas) }\end{array}$ \\
\hline $\begin{array}{r}\text { Oceanic } \\
\text { bonito }\end{array}$ & $\begin{array}{l}\text { Katsuwonus pelamis } \\
\text { Euthynnus }\end{array}$ & $\begin{array}{l}\text { Pt.Conception to Galapa- } \\
\text { gos. All year. }\end{array}$ \\
\hline $\begin{array}{l}\text { Yellowf in } \\
\text { tuna }\end{array}$ & Neothunnus macropterus & $\begin{array}{l}\text { Ft. Conception to Galapa- } \\
\text { gos. (Rare } \mathrm{N} \text { of } 35^{\circ} \mathrm{N} \text { ) }\end{array}$ \\
\hline White bass & Cynoscion nobilis & $\begin{array}{l}\text { Southern Cal.coast. May- } \\
\text { June.1; Jul.-Apr.30.2 }\end{array}$ \\
\hline $\begin{array}{l}\text { Spotfin } \\
\text { croaker }\end{array}$ & Roncador stearnsi & $\begin{array}{l}\text { Southern Cal. coast } \\
\text { Summer. }\end{array}$ \\
\hline Sea cat & $\frac{\text { Felichthys }}{\& \underline{\text { Finnimaculatus }}}$ & $\begin{array}{l}\text { Panama (Gulf of Cal.to } \\
\text { Ecuador) }\end{array}$ \\
\hline Sea cat & Galeichthys ( $6 \mathrm{sp})$. & Panama \\
\hline Sea cat & $\frac{\text { Aelurichthys }}{\text { panamensis }}$ & Panama \\
\hline Sea cat & Arius assimilis & Mazatlan \\
\hline Sea robin & Prionotus(several sp.) & Panama; 7 to $51 \mathrm{f}$. \\
\hline Crevalles & Caringidae (many sp.) & Inshore, all year. \\
\hline
\end{tabular}

Table \#4

Ispawning period

$2_{\text {Fishing period }}$ 
SPECIES SUGGESTED FOR FURTHER INVEST IGATION

IN HAWAIIAN WATERS

\begin{tabular}{|c|c|c|}
\hline $\begin{array}{l}\text { COMMON } \\
\text { NAME }\end{array}$ & $\underset{\text { NA IENT IFIC }}{\text { SAME }}$ & $\begin{array}{l}\text { CENTERS OF } \\
\text { ABUNDANCE }\end{array}$ \\
\hline Makiawa & Etrumeus micropus & Honolulu \\
\hline $\begin{array}{l}\text { Ocean } \\
\text { sunfish }\end{array}$ & $\begin{array}{l}\text { Molidae: Nola, } \\
\text { Masturus \& Ranzania }\end{array}$ & Surface; pelagic \\
\hline Demoiselles & $\begin{array}{l}\text { Pomacentridae: e.g. } \\
\text { Dascyllus albiselia }\end{array}$ & Honolulu; reefs \\
\hline $\begin{array}{l}\text { Wilkfish: } \\
\text { awa }\end{array}$ & Chanos chanos & Honolulu \& elsewhere \\
\hline $\begin{array}{l}\text { Frigate } \\
\text { mackere1 }\end{array}$ & Auxis thazard & Hilo; near surface \\
\hline $\begin{array}{l}\text { Aku or ocean } \\
\text { bonito }\end{array}$ & Gymnosarda pelamis & Hawai1; all year \\
\hline $\begin{array}{l}\text { Káwakáwa; } \\
\text { Ittle tunny }\end{array}$ & G.alletterata & Open sea; all year \\
\hline $\begin{array}{r}\text { Oceanic } \\
\text { bonito }\end{array}$ & Euthynnus yeito & Generally distributed \\
\hline $\begin{array}{l}\text { Yellowfin } \\
\text { tuna. }\end{array}$ & $\frac{\text { Neothunnus }}{\text { macropterus }}$ & $\begin{array}{l}\text { High seas; } 0 \text { to } 100 \mathrm{f.;} \\
\text { all year. }\end{array}$ \\
\hline Triggerfish & Balistidae & Numerous all year; reefs \\
\hline Crevalles & Carangidae & $\begin{array}{l}\text { Numerous all year; } \\
\text { lagoons. }\end{array}$ \\
\hline
\end{tabular}

Table \#5 
SPECIES SUGGESTED FOR FURTHER INVESTIGAT ION

IN PHILIFPINE WATERS:

\begin{tabular}{|c|c|c|}
\hline $\begin{array}{l}\text { COMMON } \\
\text { NAME }\end{array}$ & $\begin{array}{l}\text { SCIENT IF IC } \\
\text { NAME }\end{array}$ & $\begin{array}{l}\text { CENTERS OF } \\
\text { ABUNDANCE }\end{array}$ \\
\hline Tarpon & $\frac{\text { Megalops }}{\text { cyprinoides }}$ & $\begin{array}{l}\text { S.Luzon; Negros. } \\
\text { All year. }\end{array}$ \\
\hline Milkfish & Chanos chanos & $\begin{array}{l}\text { Luzon; Mindoro; Negros. } \\
\text { Breed war. Way inshore; } \\
\text { at other times offshore. }\end{array}$ \\
\hline $\begin{array}{l}\text { Spadefish } \\
\text { Angelfish }\end{array}$ & $\frac{\text { Ephippus argus }}{2 E \text { E.orbis }}$ & $\begin{array}{l}\text { Luzon; Panay; Negros; } \\
\text { Mindanao. Near shore. }\end{array}$ \\
\hline Demoiselles & $\begin{array}{l}\text { Fomacentridae } \\
\left(\begin{array}{ll}74 \mathrm{sp} .\end{array}\right)\end{array}$ & $\begin{array}{l}\text { Generally distributed } \\
\text { on reefs. }\end{array}$ \\
\hline $\begin{array}{l}\text { Thick-1 ipped } \\
\text { grunt }\end{array}$ & $\frac{\text { Flectorhynchus }}{\text { pictus }}$ & $\begin{array}{l}\text { Luzon; Cebu; Hindoro; } \\
\text { New Guinea-Japan; Fiji. }\end{array}$ \\
\hline $\begin{array}{l}\text { Oceanic } \\
\text { bonito }\end{array}$ & Euthynnus yaito & Negros \\
\hline $\begin{array}{l}\text { Yellowi in } \\
\text { tuna, etc. }\end{array}$ & $\frac{\text { Neothunnus }}{\text { macropterus }}$ & $\begin{array}{l}\text { Luzon (So.P.I.south \& } \\
\text { east to N.Guinea \& H.I.) }\end{array}$ \\
\hline Croakers & $\begin{array}{l}\text { Sciaenidae } \\
\left(8 \mathrm{sp}_{.}\right)\end{array}$ & $\begin{array}{l}\text { Generally distributed } \\
\text { near shore, on bottom. }\end{array}$ \\
\hline $\begin{array}{c}\text { Green sea } \\
\text { catfish }\end{array}$ & Arius thalassinus & $\begin{array}{l}\text { Manila } B \text {. } \\
\text { Shallow water }\end{array}$ \\
\hline $\begin{array}{l}\text { Smooth-head- } \\
\text { ed sea cat }\end{array}$ & $\frac{\text { Arius }}{\text { cephalus }}$ & San líguel $B$. \\
\hline Gurnard & $\frac{\text { Lepidotrigla }}{\text { eydouxii }}$ & $\begin{array}{l}\text { Manila. } \\
\text { On bottom. }\end{array}$ \\
\hline $\begin{array}{l}\text { oceanic } \\
\text { bonito }\end{array}$ & Katsuwonus pelamis & Luzon; Bulan; Negros. \\
\hline
\end{tabular}

Table $\frac{\pi}{\pi} 6$ 
SPECIES SUGGESTED FOR FURTHER INVESTIGATION

IN JAPANESE WATERS:

\begin{tabular}{|c|c|c|}
\hline $\begin{array}{l}\text { COMMON } \\
\text { NAME }\end{array}$ & $\begin{array}{c}\text { SC IENT IF IC } \\
\text { NAME }\end{array}$ & $\begin{array}{l}\text { CENTERS OF } \\
\text { ABUNDANCE }\end{array}$ \\
\hline $\begin{array}{l}\text { Japanese } \\
\text { sardine }\end{array}$ & $\frac{\text { Sardina }}{\text { melanosticta }}$ & $\begin{array}{l}\text { Kyushu to Sakhalin; } \mathrm{B} \text { \& } \\
\text { W coasts Japan; N coast } \\
\text { Hokkaido; E coast Korea. } \\
\text { Breed: Jan. to May. }\end{array}$ \\
\hline Sculpins & $\begin{array}{l}\text { Cottidae } \\
(12 \mathrm{sp} .)\end{array}$ & $\begin{array}{l}\text { Kuriles; Sakhalin to } \\
\text { Sagami Bay. }\end{array}$ \\
\hline $\begin{array}{l}\text { Alaska } \\
\text { cod,etc. }\end{array}$ & $\frac{\text { Gadus }}{8 \text { other }} \frac{\text { Gadidae }}{\text { Gadus }}$ & $\begin{array}{l}\text { Kamchatka; Sakhal in; } \\
\text { Kuriles; Hokkaido. }\end{array}$ \\
\hline $\begin{array}{l}\text { Alaska } \\
\text { pollock }\end{array}$ & $\frac{\text { Theragra }}{\text { chalcogramma }}$ & $\begin{array}{l}\text { Kurlies; Hokkaldo; } \\
\text { Sakhalin to Toyama } B .\end{array}$ \\
\hline $\begin{array}{l}\text { Ocean } \\
\text { sunfish }\end{array}$ & $\frac{\text { Mola }}{\text { other Mola }} \stackrel{\text { Mo }}{\text { idae }}$ & $\begin{array}{l}\text { Northward to Tokyo. } \\
\text { Near surfece. }\end{array}$ \\
\hline Grunts & $\begin{array}{l}\text { Pomadasyidae } \\
(\text { many sp.) }\end{array}$ & $\begin{array}{l}\text { Widely distributed. } \\
\text { Near shore. }\end{array}$ \\
\hline Isaki & $\frac{\text { Parapristipoma }}{\text { trilineatum }}$ & $\begin{array}{l}\text { Tokyo to Nagasak1; } \\
\text { China; Formosa }\end{array}$ \\
\hline $\begin{array}{l}\text { Korodai, } \\
\text { Koshodai }\end{array}$ & $\frac{\text { Plectorhynchus }}{\text { pletus \& } \text { P.cinctus }}$ & Tokjo to Nagasak1 \\
\hline $\begin{array}{l}\text { Oceanic } \\
\text { bonito }\end{array}$ & Katsuwonus pelamis & $\begin{array}{l}\text { Follows Kuroshlo. } \\
\text { Formosa; Hokkaido; } \\
\text { Japan \& E.China seas. } \\
\text { S. in Mar.; N.in Jul. }\end{array}$ \\
\hline Saba & $\frac{\text { Pneumatophorus }}{\text { japonicus }}$ & $\begin{array}{l}\text { Korea; Japan; E.China \& } \\
\text { Inland seas; Hokkaido E } \\
\text { to Hawa } 11 .\end{array}$ \\
\hline $\begin{array}{l}\text { Yellow- } \\
\text { fin tune }\end{array}$ & $\frac{\text { Neothunnus }}{\text { macropterus }}$ & $\begin{array}{l}\text { S of } 35^{\circ} \mathrm{N} \text {. Ryukyu, Bonin } \\
\text { Is.to Middle Hondo; Japan } \\
\text { \& E.China seas. }\end{array}$ \\
\hline Kandar i & $\begin{array}{l}\text { Colilchthys fra- } \\
\frac{\text { gilis }}{\& \text { C.Iucidus }}\end{array}$ & $\begin{array}{l}\text { Yellow \& China seas. Near } \\
\text { Moppo, Korea from mid- } \\
\text { May to late June }\end{array}$ \\
\hline Gurnards & $\begin{array}{l}\text { Chelidonichthys } \\
\text { kumu and Lepido- } \\
\text { trigla microptera }\end{array}$ & S of tolsyo \\
\hline
\end{tabular}

Table $\# 7$ 


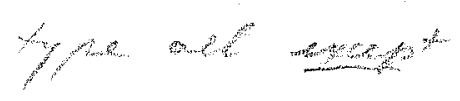

\section{B IBL IOGRAPHY}

Abbott, Charles Conrad

1877. Traces of a voice in fishes. Amer.Naturalist,

Adams, Arthur vol.11, pp.147-156.

1861. Musical fishes. Zoologist, vol.19, p.7517.

Agass 1z, Louis

1850. Manner of producing sounds in catfish and drumfish. Proc.Amer.Acad.Arts \& Sci., vol.2, p.238.

Alcock, A.

1902. A naturalist in Indian seas. John Murray, Albemarle St., London. $328 \mathrm{pp}$.

- Bigelow, Henry B. and William W. Welsh

1924. Fishes of the Gulf of Maine. Bull.U.S.Bur.Fish., vol.40, pt.1, 1924.

Bridge, T.W.

1893. Vocal organs in fishes. Amer.Midland Naturalist, vol.16, p.168.

1904. Fishes, ascidians, etc. Cambridge Nat.Hist., vol.VII, pp.355-365.

Bridge, T.W. and A.C.Haddon

1890. Contributions to the anatomy of fishes. I. The airbladder and Veberian ossicles in the siluridae. Proc.Roy.Soc.London. XLVI, vol.283, pp.309-328. II.Air-bladder and Weberian ossicles in the siluroid fishes. Ibid vol.LII, 1892, pp.139-157. Ibld, Ph11. Trans.Roy.Soc.London.CLXXXIV, pp.65-333.

1894. Note on the production of sounds by the air-bladder of certain siluroid fishes. Proc.of the Roy.Soc. London, vol.55, pp.439-441.

Bruning, $\mathrm{C}$.

1913. Ein Tonerzeugender Wels aus dem Amazonenstrom. Wochenschr.Aquar.-Terrar. Kunde 10. Jahre.,889-890. Burkenroad, Nartin D.

1930. Sound production in the Haemulidae. Copeia, vol.1, p.17.

1931. Notes on the sound-producing marine fishes of Louialana. Copeia, vol.1, pp.20-28. March 1931.

clark, Austin

1926. Anlmal noises. Sci.Mon. Jan.1926. pp.40-48. Cobb, J.N.

1908. The voices of flshes. Wash.(D.C.) Star, sunday

Coupin, Henr 1 Mag.Oct.4, 1908.

1904. Les poissons qui parlent. La Nature, vol.32. pt.1, p.379.

Cuvier, Georges

1834. The animal kingdom arranged in conformity with its organization by the Baron Cuvier, with supplementary additions to each order by Edward Griffiths and othera. Vol. $X$ Class Pisces, London. 
David, $K$.

1941. Lautausserungen beim Grunding (Gobio fluviatilis). Zool.Anz. vol.134, pp.90-91.

$\checkmark$ Day, Francis

1880. Instincts and emotions in fish. Trans.I1nn.Soc. Zool. vol.XV, No.81, Mar.1880, p.50.

Dobrin, Milton $B$.

1947. Neasurements of underwater noise produced by marine life. Sclence, vol.105, No.2714, p.19.

1947. Piscatorial concerto. Tech.Rev. Warch 1947, p.271. Dorn, $\mathrm{R}$.

1914. A note on the purring gourami. Copela, no.4, pp.1-2. Drieberg, C.

1908. Singine fish of Batticaloa. Spolia Zeylanica, vol.5. Dufossé, $\mathrm{PP}$.

1858 - 1862. Des differents phenomenes physiologlques nommés voix des poissons. C.R.Acad.Sci.raris, vol. 46, pp.352-356. Ibid vol.47, p.916; Ibid vol.54, pp.393-395.

1866. De I'ichthyopsophie ou des différents phénomènes, physiologlques nommés "voix des poissons". C.R.Ácad. Sci.Paris, vol.62, pp.978-980. Comptes Rendu.

1874. Recherches sur les bruits et ies sous expressifs que font entendre les poissons d'Europe et ser les organes producteurs de ces phénomènes acoustiques ainsi que sur les appareils de l'audition de plusieurs de ces animaux. Annales des Sciences Naturelles, 5 me ser., t.xix, 1874, art.5, $53 \mathrm{pp} ., 4 \mathrm{pl}$. and t.xx, art.3,
$134 \mathrm{pp}$.

Duméril, A.H.

1863. Des bruits que les poissons font entendre. Annaire Sci. (Déhérain) Paris, vol.2, pp.238-251.

Evermann, B. W.

1909. The singing fishes. Shields' lifag., vol.8, no.6, p.261. Firth, Raymond

1946. Malay fisherman. Kegan, Paul, French and Trubner. - Fish, Charles $J$.

1946. Oceanography in Japan. Navy. F2M-1007-46(1) Oceanography. NTJ Ser.No.112, (Index No.X-401\%) (Jap) 409-

Fish, Marie $\mathrm{P}$. 900 MS7-10 Mar.1946. 114 pp.

1948. Sonic marine mammals of the Pacific. (Unpublished manuscript).

Galton, J.C.

1874. The song of fishes. Pop.Sci.Rev. vol.13, pp.337-349. Gill, Theodore

1905. The Iffe history of the sea horses (Hippocampids). Proc.U.S.Nat.Mus., vol.28, pp.805-814. 
Girard, C.F.

1889. Les poissons musiciens. Le Naturaliste, vol.11, pp. $57-58$.

Greene, Charles $w$.

1924. Physiological reactions and structure of the vocal apparatus of the California singine fish, Forichthys

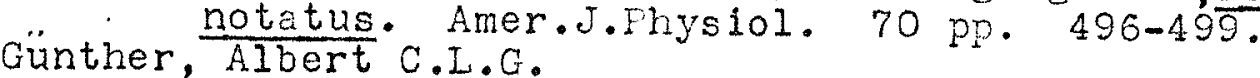

1880. An introduction to the study of fishes. Adam \& Charles Black, Eainbureh. $720 \mathrm{pp}$.

Haddon, A.C.

1881. On the stridulatine apparatus of Callomystax gagata. J.Anat.Physiol., 1881, vol.15, p.322.

Hamilton, Wiliam R.

1889. Croaking of the perch. BuIl.U.S.Fish Comm. vol.7, p. 63 .

HardenberE, J.D.F.

1933. Over geluidmakende visschen. Tropische Natuur,

Harting, $F$. vol.22(8), pp.155-158.

1862. Geluid door visschen voortgebrazt. Album.Natuur, 1862 (Wetensch.bijblad.), 43.

1874. Geluiden door visschen voortgebracht. Album. Natuur., 1874 (Wetensch.bijblad.), 56.

1880. Geluids-organen bij vischen. Albur.Natuur., 1880 (Wetensch.bijblad.), 22-23.

Herre, Albert $W$.

1940. Distribution of $\mathrm{fish}$ in the tropical Pacific. Proc. Sixth Pac.Sci.Cong.,California, 1939. vol.3, pp.587-592.

Hidaka, Koji

1946. Cooperation of Japanese oceanographers with Army and Navy during Facific war. Trans.Amer.Geophys.Union vol.27(IV), pp.517-520.

ildebrand, Samuel F.

1946. A descriptive catalog of the shore fishes of Feru. Bull.U.S.Nat.Nus.no.189, pp.1-530.

Hildebrand, Samuel ${ }^{\prime}$. and William C. Shroeder.

1927. Fishes of Chesapeake Bay. Bull.U.S.Bur.Fish. vol.43, 1927, pt.1.

Hiyama, Yoshio

1944. Abstracted report on sounds produced by aquatic animals with index to acquired disk recordings. Fak1007-46(1) Oceanography ITJ Ser.no.112 (Index No.X$40 \mathrm{~N})$, Enclosure (1).

LHolbrook, John Edwards

1860. Ichthyology of South Carolina. Ena.edition,Charles-

Holder, C.F. ton. $205 \mathrm{pp}$.

1902. Vocal sound of fishes. Sclen.Amer. vol.87, p.323 
Hubbs, Carl L.

1920. The binomics of Porlchthys notatus Girard. Amer. Jobert, C. Nat. vol.54, pp. 380-384.

1880. Sur la prétendue voix de certains poissons siluroides. C.R.Assoc.Franz.Avanc.Sci. 8.sess.1879(1880), 743 .

Johnson, M.W., F.A.Everest and R.W.Young

1947. The role of snapping shrimp (Crangon and Synalpheus) in the production of underwater noise in the sea. B101.Bull., vol.93(2), pp.122-138.

$\checkmark$ Jordan, David S. and Carl H. Elgenmann

1889. A review of the Sciaenidae of America and Europe. U.S.Fish.Comm., Commissioner's Rept. for 1886, pp. $343-451$.

Jordan, David S., B.W.Evermann, and H.W.Clark

1930. Check list of the fishes and fishlike vertebrates of North and middle America north of the northern boundary of Venezuela and Colombia. U.S.Bur.Fish., Commissioner's Rept. for 1928, pt.II, $670 \mathrm{pp}$.

Jordan, David $S$. and R.E.Richardson

1908. Fishes from the Philippine Archipelago. Bul1.U.S. Bur.Fish. vol.27, pp.233-295.

Kishinouye, Kamarkichi

1923. Contributions to the comparative study of the so-called scombroid fishes. J.Coli.Agric.Tokyo Imp.Univ., vol.8, no.3, pp.293-475.

Kyle, Harry it.

1926. The biology of fishes. Macmillan Co. ppl361-362. Sound production.

Lando is, H.

1873. Ueber die Läutausserungen mancher Fische. Mitth. Naturw.ber. Neu-borpommern Rugen, 1873-74, 5 \& 6 . Jahrg., 16-17.

Lin, Shu-jen

1935. Notes on some important scianid fishes of China. Bull. Chekiang Prov.Fish.Exp.Sta. vol.1(1), pp.1-30.

1938. Further notes on sciaenid fishes of China. Lingnan Sci.J., vol.17(1), pp.33-43; Ibid. vol.17(2), pp.161173; Ibid.vol.17(3), pp.367-381; Ibid. vol.17(4),pp. $537-550$.

1940. Croakers of the South China Sea. J.Hong Kong Fish. Res.Sta. vol.I(2), pp.243-254.

Lubach, D.

1859. Geluidgevende visschen. Album.Natuur.,1859(weteusch. bijblad.), 25.

1872. Geluid voortebracht door eenige visschen. Album.Natuur.,1873(Wetensch.bijblad.), 7 .

Haas, $K$.

1914. Ein knurrender Wels aus dem Kongo. Wochenschr.Aquar.Terrar. Kunde, Il Jahrs.,380-382. 
Major, Harlan

1948. "Giant Singing Fish". Holiday Mag. Feb.1948:p.67. Matsubara, Kiomatsu

1937. Considerations in the identification of species of Nibia in the adjacent waters of Japan. Dobutsugaku Zasshi vol.49, pp.142-143.

Mettenhelmer, C.F.C.

1858. Ueber Töne bei Knorpelfisbhen. Arch.Anat.Physiol. (Múller), 1858, pp.302-303.

Mo̊bius, Karl A.

1889. Balistes aculeatus, ein trommeluder Fisch Sitzber. der K.Preussisches Akad.Wiss.BdxłVI Berlin, pp.999-

Moreau, 1006 .

1864. Sur la voix des poissons. C.R.de I'Academie des Sciences, Paris, Aug.29, p.436.

1876. Recherches expérimentales sur les fonctions de la vessie natatoire. Ann.Sci.Nat.(Zool.) 5 ser.,vol.4, art.8.

$\checkmark$ Moseley, $K$.

1879. Notes by a naturalist on H.M.S'"Challenger" . London. Muiller, J.

1857. Ueber die Fische, welche Töne von sich zeben und die Entstehung dieser Töne. Arch.w. für Anat. Physiol.

Murray, J. (Múller), 1857, pp.249-279.

1831. Herring making sounds. Mag.Nat.Hist.1831,p.148.

1833. Fishes possess an audible volce. Mag.Nat.Hist.,1833, vol.6, p.527.

Newman, E.

1860. Musical fishes of the east. Zoologist vol.18, pp. 7179 - 7182 .

Nichols, John $\mathrm{T}$. and Paul Bartsch

1945. Fishes and shells of the Pacific world, Macmillan Company.

Nichols, John T. \& Charles Breder.

1926. The marine fishes of New York and southern New England. Zoologica, Scien.Contr.N.Y.Zool.Soc., vol.9, 1927.

N.O.L.R.No.880.

* 1944. Investigation of blological underwater background noises in vicinity of Beaufort, N.C. U.S.Navy Yard, March 1944.

Norman, John R.

1931. A history of fishes. Ernest Benn Limited London Bouverie House, E.C. 4. pp.154-158.

Okada, Nagutomi, Hidaka

1942. Discussion on: "Sound in the Sea". Science of the Ocean II(6):pp.I-18, June (Kaiyo no Kagaku)

Pappe, Carl W.I.

$\checkmark$ 1853. Synopsis of the edible fishes of the Cape of Good Hope. Capetown. $34 \mathrm{pp}$. 
Parish, C.

1871. Musical fish. Sci.Gossip 1870(1871), pp.146-148.

Parker, Georege 11 .

¿ 1904. Hearing and allied senses in fishes. Bull.U.S.Fish. Comm. vol.22, pp.45-64.

1910. Sound as a directing influence in the movements of fishes. Bull.U.S.Bur. Fish., vol.30, pp.99-104.

1910. Structure and functions of the ear of the squeteague. Bull.U.S.Bur.Fish., vol.28,pt.II. pp.1211-1224.

1911. Effects of explosive sounds, such as those produced by motor boats and guns, upon fislies. U.S.Bur. Fish., Commissioner's Rept. for 1911. Bur.Fish.Doc.No.752.

Peal, S.E. $10 \mathrm{pp}$.

1880. Voice in fish. Nature, vol.21, p.55.

Pearson, J.

1912. The singing fish of Batticaloa. Spolia Zelanica,

Pieters, D. vol.8, pp.150-151.

1933. Een luidruchtige visch. Tropische Natuur vol.22(3). pp.39-43.

Richardson, Robert $E$.

1908. A review of the flat-heads, gurnards, and other mailcheeked fishes of the waters of Japan. Proc.U.S.Nat.

Robin, C.F. lins. v01.33, 1908.

1872. Rapport sur ce mémolre (de Dufossé sur les bruits des poissons). Bull. Assoc.Scien.France, vol.11, pp. $233-236$.

L Roxas, Hilario A. and A.G.Agco

1941. A review of Fhilippine Carangidae. Fhil.J.Sci.

Santini, E. vol.74, $\mathrm{pp} .1-79$.

1898-1899. La voix des poissons. Le Naturaliste, vol.20, schäfer, $\stackrel{p}{P}$. pp.274-275; 289-290; (Suite) vol.21, pp.12-14.

1915. Knurreuder Gurami, Ctenops vittatus, und Zwerggurami, Trichogaster lalius Ham.-Buch. Blatt.Aquar.-Terrar. Kunde, 26 Jahrg.,pp.305-307.

Schiebold, A.

1912. Etwas von der Pflege des Ctenops vittatus oder knurrenden Guramis. Wochenschr.Aquar.-Terrar., 9 Jahrg. $\mathrm{pp}$.741-742.

Schultz, L.P. and E.J.Stern

1948. Ways of fishes. Van Nostrand. $264 \mathrm{pp}$.

Siroth, Heinrich R.

1897. Ueber Stimme und Gehor und ihre Abhangigkeit vom Skogsberg, Tage Landesleben. Nat. Wochenschr. vol.12, pp.331-332.

$\checkmark$ 1939. Fishes of the family Sciaenidae (Croakers) of California. Bull.Cal.Fish \& Game, no.54, $62 \mathrm{pp}$. 
Skomorowski, T.

1875. Organa muzyczne ryb. Przyroda i Przemysl, vol.4, pp.10-11; 54-55; 77-79.

Smith, Hugh $\mathrm{H}$.

1905. Druming of sciaenids. Science, sept.22, pp.376-378.

1927. The so-called musical sole of Siam. J.Siam Soc.Nat. Hist.Suppl. vol.7(1), pp.49-54.

Smith, Osgood $R$.

1945. The location of sardine schools by supersonic echoranging. Comm.Fish Rev., vol.9(1), pp.1-6.

Sørensen, W.E.

1879. On the apparatus of sound in some South American fishes. Ann.Mag.Nat.Hist. 5 ser., vol.4, pp.99-100.

1884. On lydorganer hos fiske. En physiologisk of comparativ-anatomish undersogelse. Kjфbenhavn, 1884, VIII, $245 \mathrm{pp}$. Inaȟg. Dissert.

1894. Are the extrinsic muscles of the air bladder in some Siluroidae and the "elastic spring" apparatus of others subordinate to the voluntary production of sounds, etc. J.Anat. and Physiol. vol.29, pp.109139 ; 205-229; 399-423; 518-552.

1896. Some remarks on Dr. Thilo's memoir on "Die Umbildungen an den Gliedmassen der Fische." Morph.Jahrb., 25, pp.170-189.

Spicer, W.W.

1871. Musical fish. Sci.Goss ip 1870 (1871), pp.57-58.

Tamada, T.

1941. Sonic Pishes.. Zennan fishery Exp.Sta. Kalyo no

Tang, D.S. Kagaku vol.1(2), p.53. July 1941 .

1937. A study of sciaenoid fishes of China. Amoy Mar.Biol. Buli., vol.2(2), $88 \mathrm{pp}$.

Thompson, J.

1830. Voice of fishes. Mag.Nat.Hist. vol.3, p.147.

Tower, Robert $w$.

1906. The voices of fishes. Bull.U.S.Z001.Soc. v01.21, pp.131-5.

1908. The production of sound in the drumfishes, the searobin and the toadfish. Ann.N.Y.Acad.Sci. vol.XVIII, no.5, pt.II, pp.149-180.

Uchida, Koji

1933. Life history of Pempheris japonicus Doderlein. Dobutsu Gaku Zasshi, vol.45, no.535, p.217.

1934. On the sound-producing fishes of Japan. Nithon Gakujitsu Kyokai Hokoku, vol. IX, no.2, May 1934 .

1939. Story of croaking (crying) fishes. Pamph.II, Fish.Exp. Sta.,Gov.Gen.Chosen. (Wash.Doc.Cent.Copy No.359433).

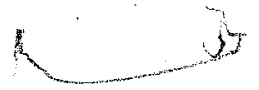




\section{Weber}

1850. De aure et auditu hominis et animalium. Pars 1 , Leipzig.

Weber, Max and L.F.DeBeaufort

Weiss, 0 .

1911-1940. The fishes of the Indo-Australian Archipelago. vols.I-VIII. E.J.Br111, Leiden 1911-1940.

1908. Erzeugung von Geräuschen und Tonen. Winterstein's White, J. Handbuch bergl. Physiol. 3(1), pp.249-318.

1824. Voyage to the seas of China. Yabe, $\mathrm{H}$.

1941. Collichthys occurring in the waters adjacent to

Yamada, T. Korea. Suisan Gakkwa1 Ho vol.8, pp.173-183.

1941. Sea where fishes croak. Kalyo no Kagaku, vol.1(2), July, 1941.

Yamada, T., Zennan Fishery Experiment Station.

1941. Sonic (sound-making) fishes. Kalyo no Kagaku, $\operatorname{vol} .1(1-2), p .53$.

Zachrias, Otto

"Trommelude Fische". 4 pages. Hentioned by sørensen. Zur Mühlen, M.

1911. Fiskar med "mal" 1 mun. Fran Skog och Sjo, vol.4,. p.236. 


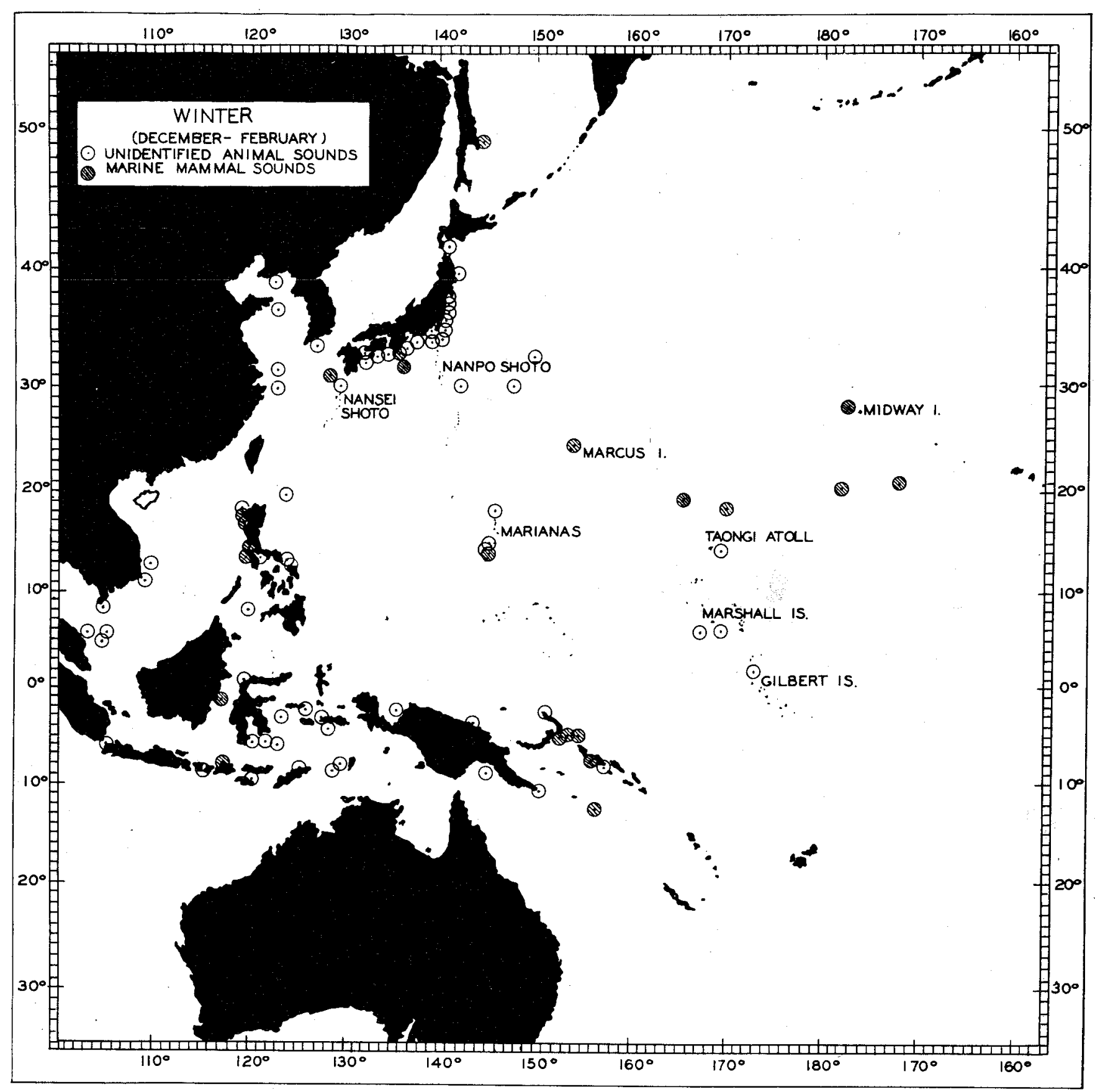

CHART I - Winter distribution of marine animal sounds reported by U.S. submarines. 


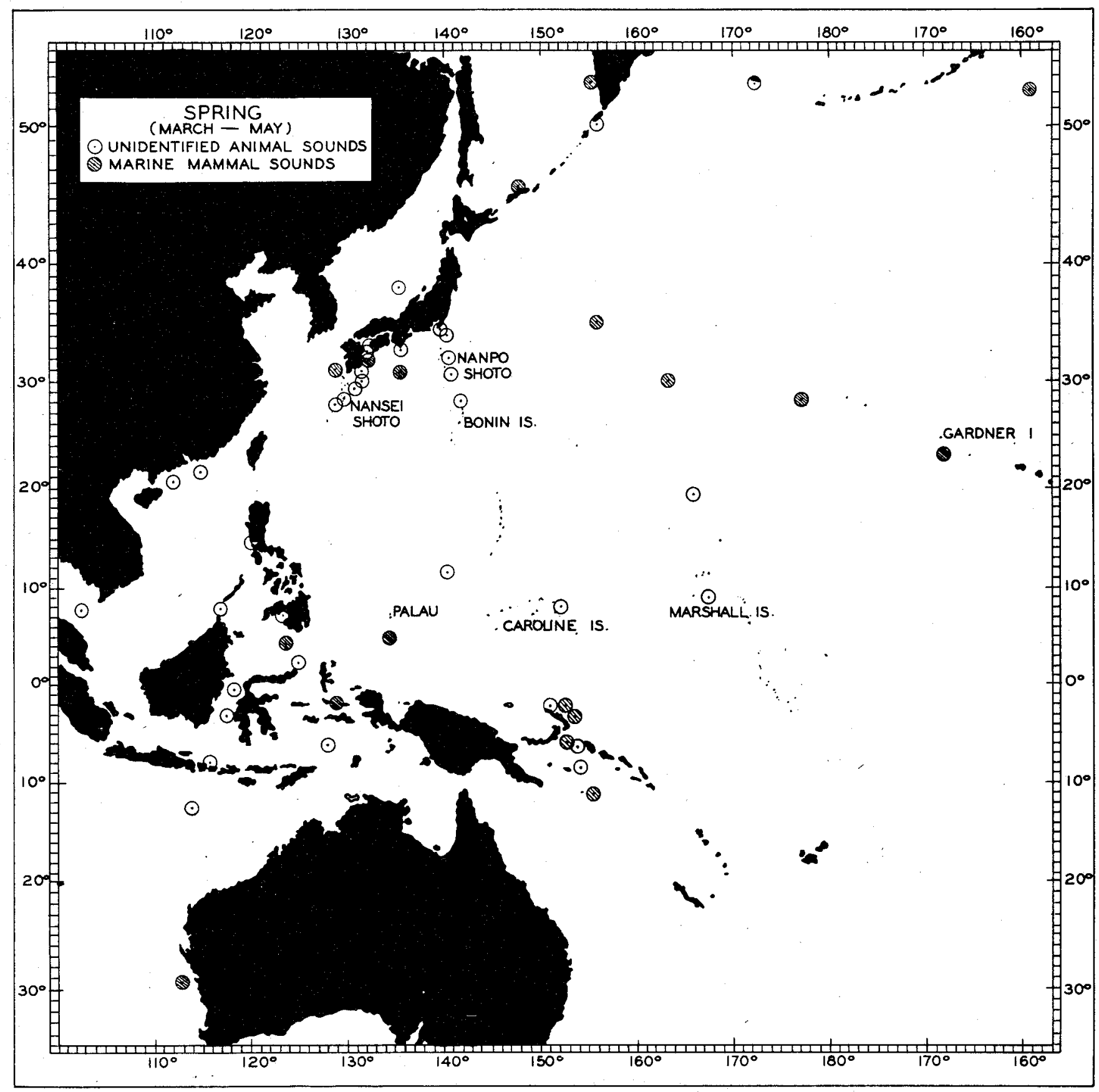

CHART II - Spring distribution of marine animal sounds reported by U.S. submarines. 


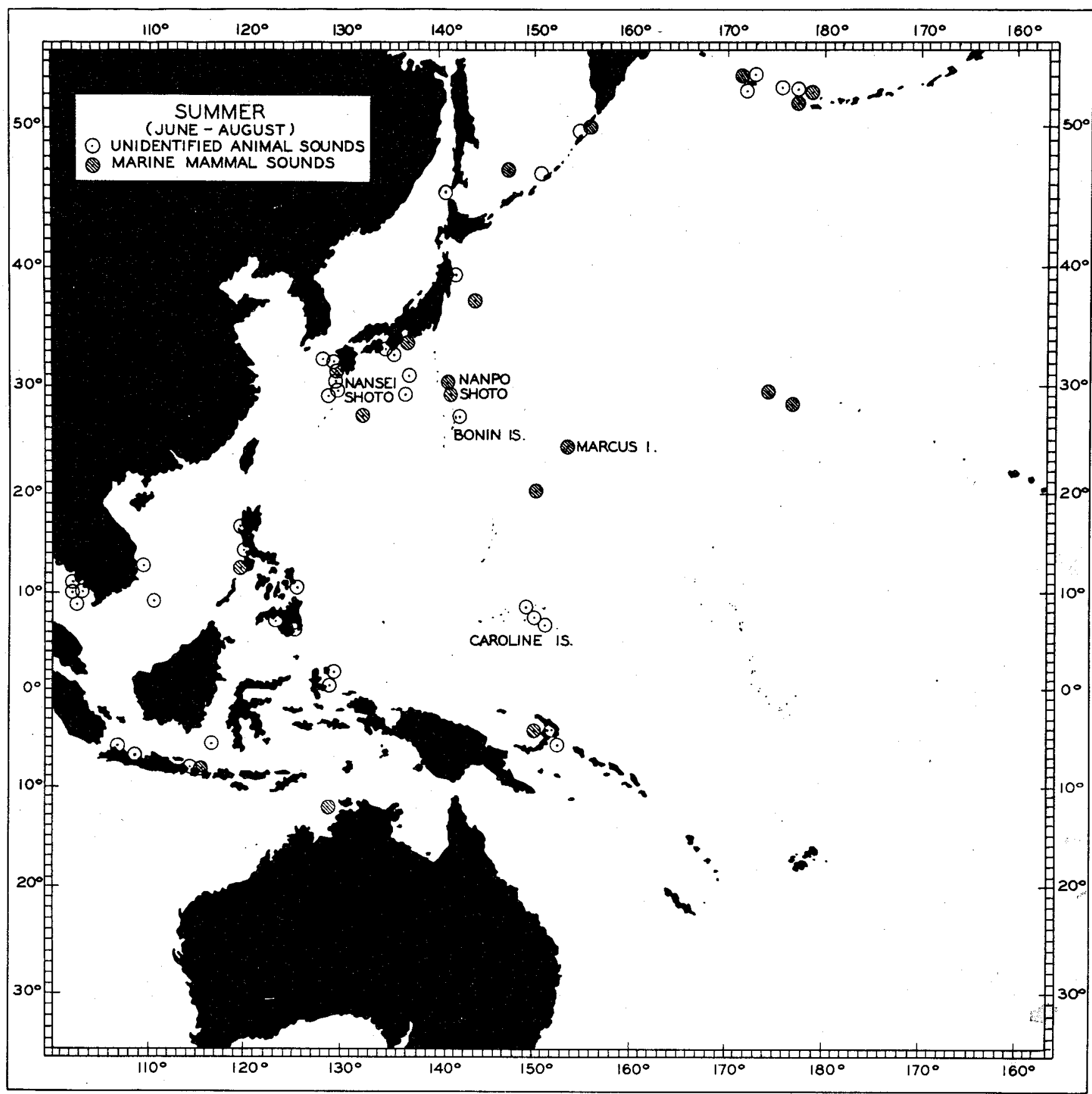

CHART III-Summer distribution of marine animal sounds reported by U.S. submarines. 


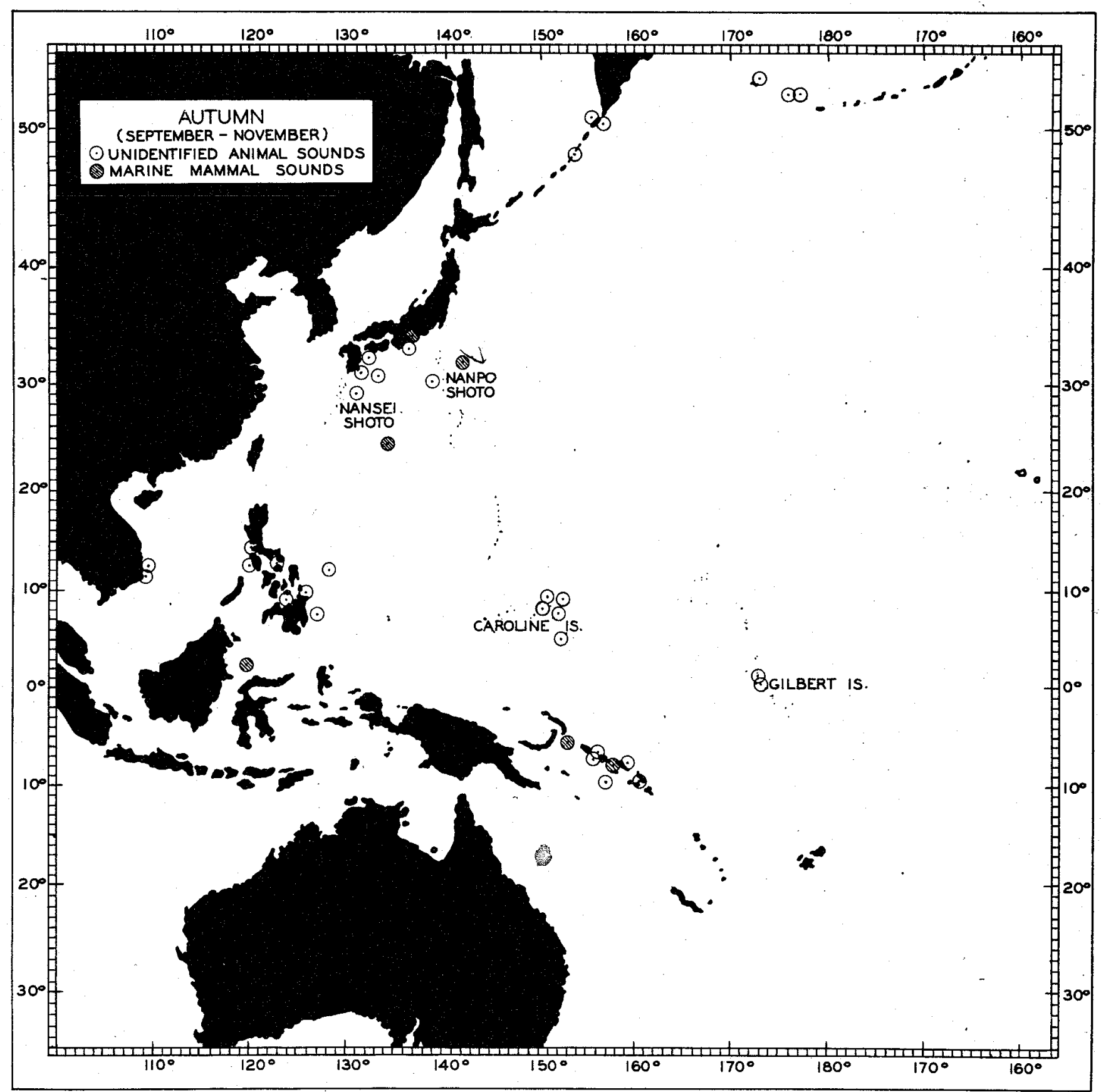

CHART IV-Autumn distribution of marine animal sounds reported by U.S. submarines. 